\title{
Policy Responses to the COVID-19 Pandemic in Vietnam
}

\author{
Tuyet-Anh T. Le ${ }^{1,2,3, *}$, Kelly Vodden ${ }^{1,3, *}$, Jianghua $W^{1}{ }^{1}$ and Ghada Atiwesh ${ }^{4}$ \\ 1 School of Science and the Environment, Grenfell Campus, Memorial University of Newfoundland, \\ Corner Brook, NL A2H 5G4, Canada; jwu@grenfell.mun.ca \\ 2 Forestry Economics Research Centre, Vietnamese Academy of Forest Sciences, 46 Duc Thang Ward, \\ Northern Tu Liem District, Hanoi 11910, Vietnam \\ 3 Environmental Policy Institute, Grenfell Campus, Memorial University of Newfoundland, Corner Brook, \\ NL A2H 5G4, Canada \\ 4 Department of Environmental Science, St. John's Campus, Memorial University of Newfoundland, \\ NL A1C 5S7, Canada; ga1871@mun.ca \\ * Correspondence: tatle@mun.ca (T.-A.T.L.); kvodden@grenfell.mun.ca (K.V.)
}

check for updates

Citation: Le, T.T.; Vodden, K.; Wu, J.; Atiwesh, G. Policy Responses to the COVID-19 Pandemic in Vietnam. Int. J. Environ. Res. Public Health 2021, 18, 559. https://doi.org/10.3390/ ijerph18020559

Received: 26 October 2020 Accepted: 30 December 2020 Published: 11 January 2021

Publisher's Note: MDPI stays neutral with regard to jurisdictional clai$\mathrm{ms}$ in published maps and institutional affiliations.

Copyright: (C) 2021 by the authors. Licensee MDPI, Basel, Switzerland. This article is an open access article distributed under the terms and conditions of the Creative Commons Attribution (CC BY) license (https:// creativecommons.org/licenses/by/ $4.0 /)$.
Abstract: The COVID-19 pandemic has become one of the most serious health crises in human history, spreading rapidly across the globe from January 2020 to the present. With prompt and drastic measures, Vietnam is one of the few countries that has largely succeeded in controlling the outbreak. This result is derived from a harmonious combination of many factors, with the policy system playing a key role. This study assessed the policy responses to the COVID-19 pandemic in Vietnam from the early days of the outbreak in January 2020 to 24 July 2020 (with a total of 413 cases confirmed and 99 days of no new cases infected from the local community) by synthesizing and evaluating 959 relevant policy documents in different classifications. The findings show that the Vietnamese policy system responded promptly, proactively, and effectively at multiple authority levels (33 different agencies from the national to provincial governments), using a range of policy tools and measures. Parallel to the daily occurrence of 2.24 new cases, 5.13 new policy documents were issued on average per day over the study period. The pandemic policy response over the first six months in Vietnam were divided into four periods, I (23 January-5 March), II (6-19 March), III (20 March-21 April), and IV (22 April-24 July). This paper synthesizes eight solution groups for these four anti-pandemic phases, including outbreak announcements and steering documents, medical measures, blockade of the schools, emergency responses, border and entry control measures, social isolation and nationwide social isolation measures, financial supports, and other measures. By emphasizing diversification of the policy responses, from the agencies to the tools and measures, the case study reviews and shares lessons from the successful COVID-19 prevention and control in Vietnam that could be useful for other nations.

Keywords: coronavirus; COVID-19 in Vietnam; pandemic in Vietnam; policy documents; policy tools; policy responses; policy measures; Vietnam

\section{Introduction}

The first confirmed case (CC) of the COVID-19 disease outside of China appeared in Thailand on 13 January 2020 [1,2]. Just 18 days later, on 30 January, in the first report on the epidemic situation, the World Health Organization (WHO) claimed that there were a total of 7818 global confirmed cases (CCs) with the majority coming from China, and only 18 cases from 18 other countries [1]. Globally, as of 24 July 2020, the COVID-19 coronavirus had spread in 213 countries and territories, with 15,296,926 CCs and a death toll of 628,903 individuals [3]. Compared to the number of CCs on 30 January, the 24 July number had increased 1956.63 times over nearly six months. The date of 24 July also marked the day with the highest number of new cases (NCs) in the past six months (284,196 NCs) [3-5]. COVID-19 deaths also reached a peak on 24 July of 9753 deaths since a record high of 9797 deaths on 30 April [3-5]. In contrast, no one had died due to COVID-19 
in Vietnam, and the number of recovered cases (RCs) had reached 365 patients $(88.38 \%)$ of the total of 413 CCs, as of 24 July. Only 48 cases were being treated (11.62\%) [6,7]. As of this date, 99 days in Vietnam had been spent without any NCs infected from the local community [8,9]. In this study, we offer an overview of the pandemic prevention and control in Vietnam, which was successful and effective, up to 24 July. The overview was divided into four periods: I (23 January-5 March), II (6-19 March), III (20 March-21 April), and IV (22 April-24 July) [10]. Within the scope of this study, the CCs and policy responses and actions put in place to minimize infection and spread over the initial six-month term from 23 January to 24 July were gathered, analyzed, and assessed.

With CC number (\#) 416 on 25 July [11-14], the 100-day series of COVID-19 noninfectiousness in Vietnam was terminated [11]. This marked the beginning of period V, with complicated and unpredictable developments in terms of both the pandemic [15] and social safety due to a series of Chinese people entering Vietnam illegally through border roads and waterways [16]. As of 15 December, the whole country had recorded 35 deaths and 1405 CCs [6]. From 25 July to 15 December (144 days) an additional 992 NCs were reported-equivalent to $6.89 \mathrm{NCs} /$ day on average, in contrast to the $2.24 \mathrm{CCs} /$ day in previous periods ( 184 days with $413 \mathrm{CCs}$ ). In the first days of period $\mathrm{V}$, there were up to dozens of NCs daily for many consecutive days. Period V also saw 35 deaths, following a period of no deaths because of the coronavirus in all four previous stages [17]. The main cause was identified as a mutation of the virus, leading to infection in the family and high cross-infection [18]. This was the sixth identified strain of COVID-19 in Vietnam, with the characteristic of spreading faster than previous strains recorded [16]. As of 15 December, Vietnam had witnessed 79 days with no more deaths, remaining at a confirmed number of 35 since 3 September [6].

Therefore, a question arises: Why in so many nations and territories across the world, including the most wealthy countries such as the USA, Brazil, France, the UK, and Germany, did the pandemic spread and cause hundreds, even thousands of deaths daily [19,20], whereas in Vietnam - a small, densely populated neighbor of China with only $331,698 \mathrm{~km}^{2}$ land area [21] and over 97.43 million people [22] that is a developing country with limited resources-was able to effectively control the COVID-19 pandemic [19,23,24]? Many wealthier countries have praised Vietnam's response to COVID-19 [20]. George Black-a writer in New York City (USA) has considered that "Vietnam may have the most effective response to the COVID-19 through mass mobilization of the health care system, public employees, and the security forces, combined with an energetic and creative public education campaign" [25] whereas Fages showed that four factors, including quick strategic testing, aggressive contact tracing, an effective public communications campaign, and swift development of testing kits, have led to other countries praising Vietnam [20]. In some studies, Vietnamese scholars pointed to the prompt and effective policy responses as one of the most important factors contributing to COVID-19-related successes in Vietnam. The study by La et al., for example, demonstrated that timely policy responses to the outbreak from the government and the media, integrated with updated research on COVID-19, together provided reliable sources of information [26]. Another survey conducted by Lê and Nguyễn also demonstrated that many countries and international organizations praised Vietnam for the resolute and prompt solutions of governments to prevent and control the pandemic, including the effective measures in quarantining and classifying people from pandemic zones [27]. This study offers an overview of the policy responses to the COVID-19 pandemic in Vietnam from the preparation phase on 16 January (before the first 2 CCs on 23 January) to 24 July by synthesizing and evaluating the relevant policy system in different classifications, including by agencies, time periods, types of policy communication, and category of policy responses.

\section{Materials and Methods}

Data on CCs were compiled from https://ncov.moh.gov.vn/web/guest/trang-chuthe website of the Ministry of Health (MOH) in Vietnam on the COVID-19 pandemic 
status updates, as well as the related study by La et al. [26]. We further report findings from collecting, classifying, and synthesizing 959 COVID-19 policy documents (PDs) from different government levels from central (national) to provincial. These PDs were gathered through two main channels: (1) https: / / thuvienphapluat.vn/ (legal library) — the most powerful website on Vietnamese legal documents-and (2) https:/ / ncov.moh.gov.vn/web/ guest/chinh-sach-phong-chong-dich-a portal opened on the MOH's website on the COVID-19 pandemic prevention and control policies.

Other relevant documents were also obtained from database analysis of recent policies, official press, articles, reports, briefs, and presentations from reliable data sources in Vietnam and globally. A total of 236 documents were obtained during the period of analysis.

Within our research, PDs under the provincial level (districts and communes) were not collected for analysis. Although at the 13th National Assembly session, the district and commune authorities officially obtained the right to issue legal documents after 22 June 2015 [28], so far, there is no official channel for storing COVID-19 PDs promulgated by district and commune levels.

After these documents were identified and collected, the analysis steps included (i) mapping a chronology of all CCs from the first day of outbreak in Vietnam (23 January) to the last day of the term (24 July) in each of four periods of the pandemic development in Vietnam, as declared by the Prime Minister (PM): I (23 January-5 March), II (6-19 March); III (20 March-21 April), and IV (22 April-24 July) (findings are in Section 3.1); (ii) classifying and synthesizing the PDs released by 33 different agencies and by periods (findings in Section 3.2) and PD types (resulting in the identification of nine key categories of PDs) (findings in Section 3.3); and lastly analyzing the evolution of policy according to the four periods of the pandemic development (findings in Section 3.4).

\section{Results}

\subsection{Chronology of New and Confirmed Cases}

Figure 1 and Figure S1 show a timeline of the spread of COVID-19 in Vietnam, tracing from the first two CCs on 23 January to CC \#413 on 24 July 2020. The data sources of this study from CC \#1 (on 23 January) to CC \#207 (on 31 March) have been drawn and then checked from La et al. [26] and from CC \#208 (on 1 April) to CC \#413 (on 24 July) from the MOH's website [6]. Corrections were made to some inaccurate information points about 4 CCs in La et al.'s study [26], including the appearance of two CCs on 3 February 2020, \#8 [29] and \#9 [30], not only one CC, \#8, as suggested by La et al. [26] and corrections to the nationalities of CCs \#151, \#152, \#186, and \#207.

The classifications of COVID-19 patients and direct contacts are defined from F0 to Fi ( $\mathrm{i}=1,2,3$, or more). To specify, F0 people are confirmed as infected, F1 people are suspected as infected or contacted F0, and F2 people contacted F1 and similarly the next generations F3, F4, etc. [31,32]. The map of 413 CCs (Figure 1) illustrates that with timely and drastic government policy responses, the rate of infection after F1 strongly declined. The whole country has 24 F0 CCs (5.81\%), which resulted in 48 F1 CCs $(11.62 \%)$. This led to 12 F2 CCs (2.91\%) out of a total of 413 CCs. In each of the F3 and F4 generations only one CC appeared, which originated from CC \#133-one of the super infectious cases and the fastest spreading case in period III (20 March-21 April) - the time with the highest number of cases of infection in the country [10].

24 July 2020 was the 184th day of fighting against the COVID-19 pandemic in Vietnam since the first two cases on 23 January. During these 184 days, there was a total of 413 CCs nationwide. Over more than six months of combat, an average of $2.24 \mathrm{NCs}$ per day were detected. There were 365 RCs [7] out of 413 CCs [33] (accounting for $88.38 \%$ ), of which the first 16 CCs were completely recovered, 349 CCs from 6 March to 20 July were recovered, and 52 CCs were being actively treated (12.47\%) [6]. According to statistics of the MOH [6], of the 413 CCs, 70 (16.95\%) were foreign nationalities (of which 49 had recovered with 
treatment by Vietnamese doctors) and 343 were Vietnamese CCs (including 237 people having returned from abroad).

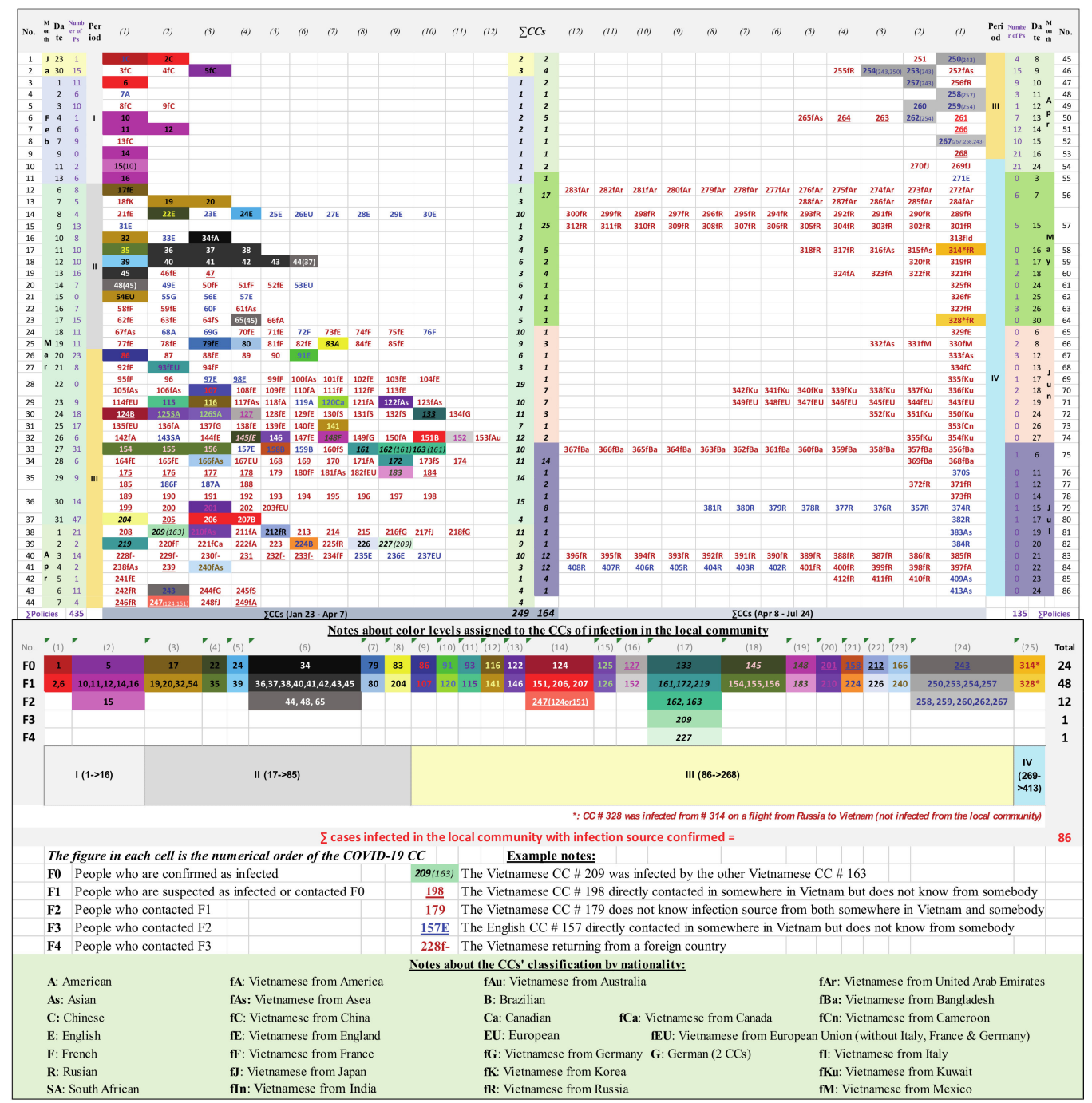

Figure 1. Chronology of COVID-19 confirmed cases (CCs) and the numbers of policy documents (PDs) in Vietnam (as of 24 July 2020).

The first period in the fight against COVID-19 in Vietnam consisted of 16 patients confirmed in 43 days (23 January-5 March, 2020), corresponding to 0.37 CC/day, who all had a history of movement from China-the country where the outbreak first appeared [34], with two Chinese, one American, and 13 Vietnamese patients [6]. The second period lasted two weeks (6-19 March) and confirmed a total of 69 cases, corresponding to 4.93 CCs/day on average, 13.25 times higher in comparison to the first period. Within period I there appeared one special CC (\#5) on 30 January, who was one of three first Vietnamese CCs of an eight-member delegation sent by Nihon Plast Co., Ltd. (Vinh Phuc province) to train in Wuhan city for 2.5 months. CC \#5 then infected six other CCs in Vinh Phuc [35,36]. Meanwhile on 6 March, Hanoi announced the first CC (\#17) returning from England [10,37], who infected four CCs (\#19, \#20, \#32 and \#54) (see Figure 1). With CC \#17, Vietnam ended a consecutive string of 22 days without any NCs and officially entered the second phase with CCs coming from abroad $[37,38]$. The most super contagious case (SCC) in this period was CC \#34 who returned from Washington (USA) to Ho Chi Minh city (HCMC) on 10 March, and then infected 11 other cases [37], including eight F1 CCs and three F2 CCs (see Figure 1). 
Compared to periods I and II, period III (20 March-21 April) occurred over the highest number of 33 consecutive days with recorded NCs due to positive test results with the new strains of COVID-19 from both Vietnamese and foreign passengers from the flights from period II, still having flights to welcome repatriated Vietnamese, and especially outbreaks of infectious chains in the community. This phase recorded a total number of 183 CCs ( 5.55 CCs per day on average), of which there were up to 54 CCs related to infectious chains in the community (accounted for $29.51 \%$ ). Notably, this period had three SCCs, \#124 and \#133 on 24 March and \#243 on 6 April (see Figure 1). On 24 March, with the detection of CC \#124 (infected from Buddha bar-the location of the highest infection in HCMC with a total of eight CCs as of 25 March and closed since 21 March [39-42], it was discovered to be the source of infection for $11 \mathrm{~F} 1$ people and $19 \mathrm{~F} 2$ people, which resulted in three F1 CCs and one F2 CC [43]. The date of 24 March was also the day of detection of CC \#133, which was considered the most SCC by creating four COVID-19 CC generations with three F1 CCs out of a total of $43 \mathrm{~F} 1$ people who were in contact with CC \#133, two F2 CCs out of a total of $699 \mathrm{~F} 2$ people who were in contact with some of the $43 \mathrm{~F} 1$ people and one F3 CC out of a total of more than 2100 F3 people and one F4 CC $[40,41]$. The date of 6 April recorded another SCC - CC \#243, who had been treated at Bach Mai hospital $[44,45]$ and then infected four F1 CCs and five F2 CCs (see Figure 1 and Figure S1).

Period IV existed for 94 days (22 April-24 July) and confirmed a total of 145 cases (1.54 CCs/day) and 280 PDs (see Figure 1 and Figure S1). The most significant and widely noted aspects of stage IV were, first, that the pandemic was well controlled [46], with all CCs originating from flights welcoming returning overseas Vietnamese. As of 24 July, Vietnam had experienced 99 days without new infections from the community [8]. Second, there was an acceptance of the situation of living with the pandemic, to move to a longer, more radical, anti-outbreak stage along with socio- economic development [47].

In brief, over the first six months of combatting COVID-19, Vietnam detected an average of 2.24 CCs and 1.98 RCs per day, which means that each day added 0.26 more NCs to treat. This indicator can be compared to other countries considered to have strong pandemic management in the first stages, such Taiwan, Hong Kong, Singapore, and South Korea [48-50]. Databases of international statistics organizations [51,52] demonstrate that these figures in Taiwan and Hong Kong were 0.1 and 5.22, respectively [48-53]. As of 24 July, Taiwan had spent 185 days in the outbreak and detected 458 CCs [51,52], corresponding to 19 CCs per 1 million population [51] and 2.48 CCs per day. These figures in Vietnam were only 4 CCs / 1 million population [51] and 2.24 CCs/day. These typical indicators illustrate that Vietnam attained significant achievements in the global fight against the COVID-19 pandemic. Despite an increase in the second COVID-19 pandemic wave from the last days of July to September, these successes in the first wave of the COVID19 pandemic remain notable and offer lessons for fighting COVID-19 and future pandemics.

\subsection{Urgent and Timely Policy Responses by All Relevant Authorities}

Vietnam carefully prepared to respond to the pandemic before the appearance of the first two positive cases from Wuhan, China, on 23 January, 2020 [26,45], which were confirmed at Cho Ray hospital in HCMC, just two days before the Lunar New Year holidays [34]. News of a "strange pneumonia" in China had circulated in Vietnamese media as early as the beginning of January 2020, before the first CCs [26]. The term "strange pneumonia" first arose on 9 January on baochinhphu.vn— the Vietnam Government Portal [54], and suckhoedoisong.vn - the official news channel of the Ministry of Health (MOH) [55], followed by a reference again in Vietnam News-the national English language daily (vietnamnews.vn) on 17 January [56].

Before 23 January, there were seven COVID-19-related official legal documents. The terms "pneumonia" and "novel coronavirus" were first announced widely on 31 December, 2019 [1]. In other words, although the information about the COVID-19 epidemic in December 2019 was not official, the MOH in Vietnam issued decision No. 5894, dated on 19 December 2019 about "Guidelines for the establishment and operation of Quick 
Response Teams (QRTs)." This document was designed to guide the establishment and operation of the QRTs from the national to the district level to respond promptly and effectively to infectious epidemics and public health events in the context of an increasing number of new and reappearing epidemics that have serious impacts on people's health as well as global health security [57]. The first legal document related to the term "coronavirus" was officially released by the Government Office (GO) with dispatch No. 441 dated 16 January, 2020, about the pneumonia epidemic in China [58-62]. On the same day, the $\mathrm{MOH}$ expeditiously issued decision No. 125 on guidelines for the diagnosis and treatment of acute pneumonia caused by a new strain of coronavirus (nCoV) [63-65]. The next day, 17 January, there were two documents issued by the $\mathrm{MOH}$, decision No. 137 on promulgating the plan for the prevention and control of the infectious epidemic in 2020 [66], and emergency dispatch No. 62 on early detection and good preparation for the prevention and control of the epidemic [65-67].

Immediately, the People's Committee (PC) of Lang Son province also directed the response to the pneumonia epidemic from China [58]. Lang Son-one of seven provinces of Vietnam bordering China-is a northern province with the largest number of border gates to China in nine locations: Huu Nghi, Dong Dang, Chi Ma, Binh Nghi, Coc Nam, Po Nhung, Co Sau, Ban Chat, and Na Hinh [68]. From 20 to 22 January, each day witnessed one legal document released by this ministry: Decision No. 156 provided a plan to respond to the epidemic [69], decision No. 181 provided temporary guidelines for surveillance and prevention and control of the epidemic for hospitals and clinics nationwide [45,70,71], and directive No. 03 (dated 22 January) focused on strengthening the prevention and control of the epidemic [72]. These legal documents were the first ministerial documents and dealt directly with the core professional problems of providing diagnosis and treatment guidelines, plans for acute pneumonia that were published one week earlier than the first CCs in Vietnam. This points out the proactive nature and high level of preparedness to cope with the pandemic that existed in the country.

Figure 2 and Figure S2 provide an overview of 413 CCs and 959 policy documents (PDs) in Vietnam from 13 January to 24 July. New PDs were issued almost every day. On average, each day 2.24 NCs appeared and 5.13 new PDs were issued as of 24 July 2020. Although only the first 16 cases coming from China [10,37] were confirmed in the 43 days of period I (23 January-5 March), the emergency PDs were issued promptly with 190 documents (4.42 PDs/day on average). In some early days there were up to 15-17 PDs/day. Meanwhile the 14 days of the second period (6-19 March) witnessed 69 CCs and-with CCs from abroad [10,37]-125 relevant PDs, corresponding to $4.93 \mathrm{CCs} /$ day and 8.93 PDs/day on average, 13.25 times and over two times higher than those in the first period, respectively. During all 33 consecutive days of period III (20 March-21 April) 183 CCs (5.55 CCs/day) and 125 PDs (10.82 PDs/day) were recorded as the infection escalated in the country $[10,37]$. New PDs at all levels, especially at the provincial levels, were issued every day to strengthen the pandemic management in the new context of complicated developments. With the entire nation's effort, the serious situation of period III led to period IV (22 April-24 July, 94 days), with policy concentrated on both fighting against the pandemic and developing strategies for dealing with relevant socio-economic consequences [10,37]. This period confirmed a total of 145 cases and 280 PDs, corresponding to $1.54 \mathrm{CC}$ / day-the second lowest figure in all periods, and $2.98 \mathrm{PDs} /$ day-the lowest number in the whole time studied (23 January-24 July) (see Figure 2 and Figure S2).

\subsubsection{Policies by Levels and Agencies}

To examine the levels and agencies in which policy actions were taken, four relevant policy levels were identified from the highest level (central/national government) to the lowest (provincial) (see Figure 3 and Figure S3). The classification of four PD levels of management is based on the organizational diagram of the State of the Socialist Republic of Vietnam in 2016 [73]. All PDs from this study were categorized by the issuing authority at each level. 


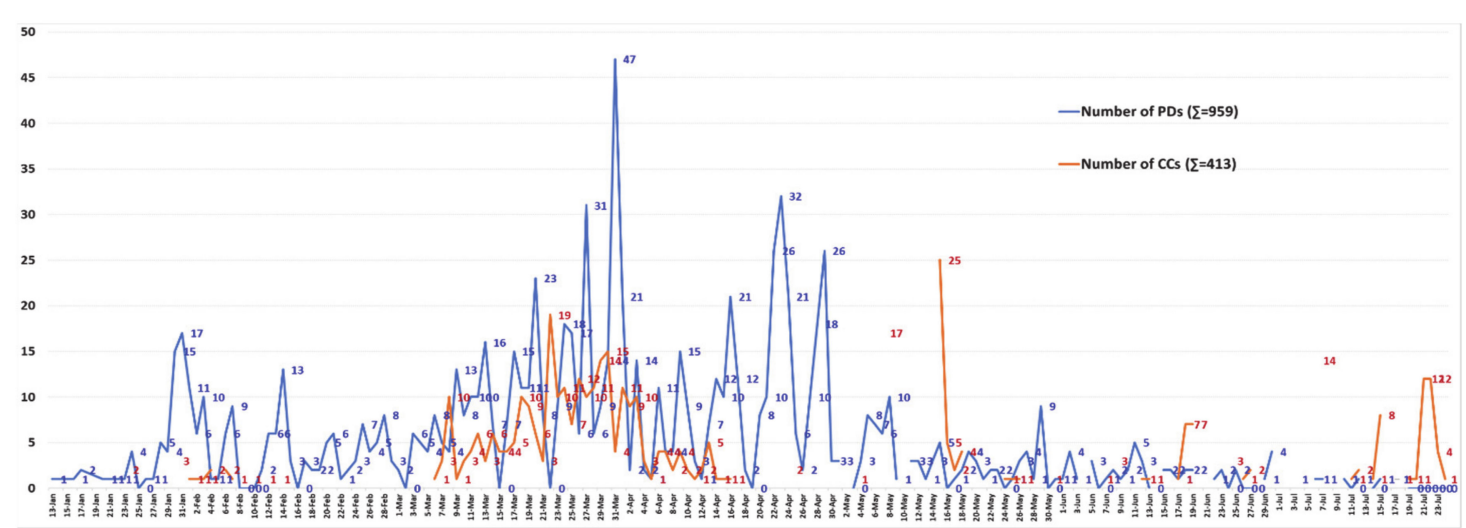

Figure 2. Numbers of CCs and PDs released (as of 24 July 2020).

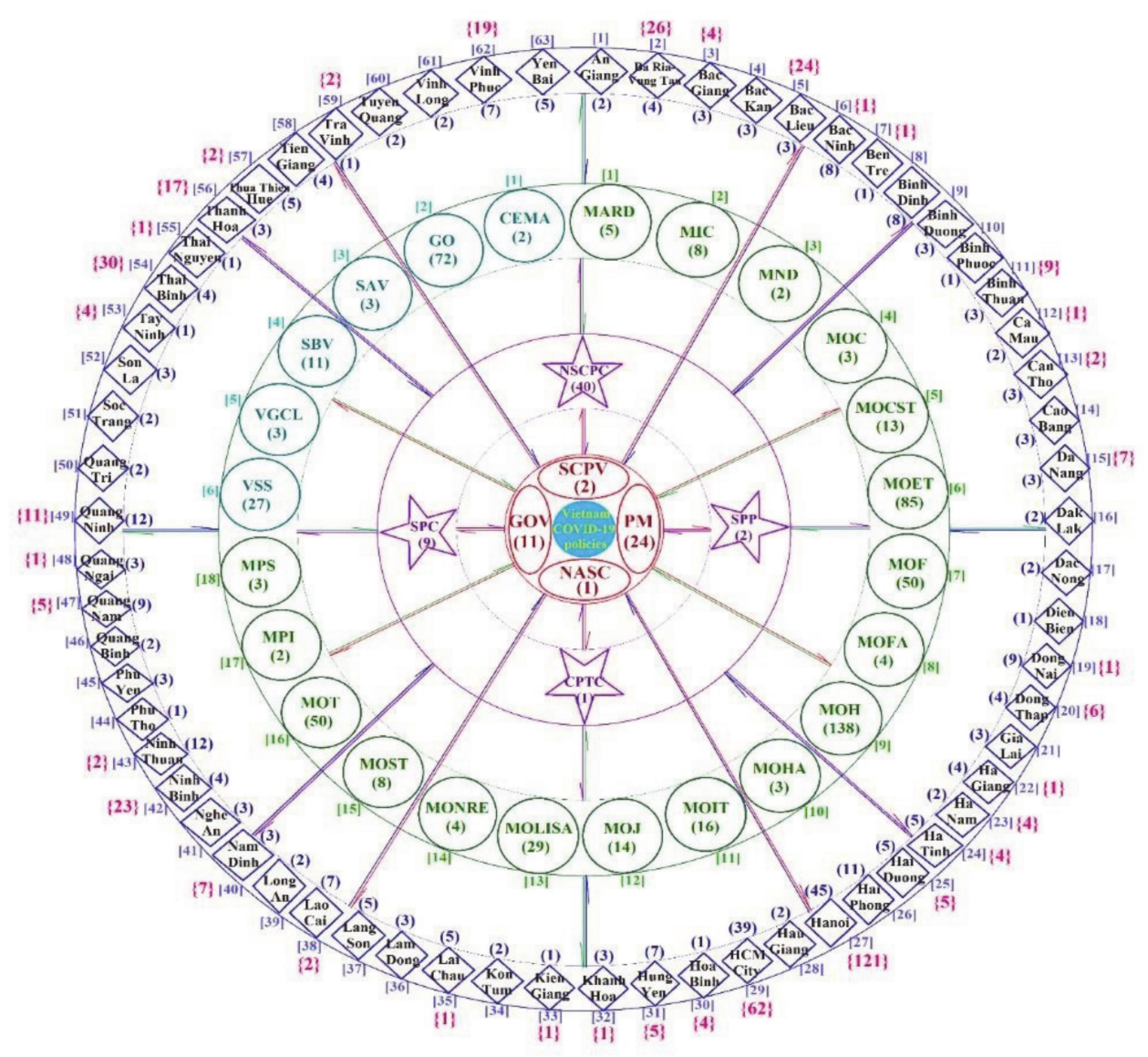

Figure 3. The map of nationwide policy responses to COVID-19 in Vietnam (as of 24 July 2020). (Notes: The number of PDs are in ( ) and the number of CCs of each province are in \{\} ; ordinal number of units due to the alphabet from A-Z at the same level are in [ ]).

Figure 3 and Figure S3 illustrate the number of Vietnamese COVID-19 PDs of each authority, as well as the qualitative relationships between PDs classified by authority levels and the number of CCs of each province, from the earliest days of the outbreak to 24 July. The information of central levels (CLs) is represented by the inner red circle, central focal agencies (CFLs) in purple, ministerial agencies in green, and provincial people's committees (PPCs) in blue. Specifically, the central levels (CLs) include four units: the National Assembly Standing Committee (NASC), Government of the Socialist Republic of Vietnam (GOV), Prime Minister (PM), and Secretariat of the Communist Party of Vietnam 
(SCPV), and the central focal agencies (CFLs) cover four units: the Central Propaganda and Training Commission (CPTC), National Steering Committee for COVID-19 Prevention and Control (NSCPC), the Supreme People's Court (SPC), and the Supreme People's Procuracy (SPP). The ministerial agencies (MAs) include 18 ministries: (1) Ministry of Agriculture and Rural Development (MARD), (2) Ministry of Information and Communications (MIC), (3) Ministry of National Defense (MND), (4) Ministry of Construction (MOC), (5) Ministry of Culture, Sports and Tourism (MOCST), (6) Ministry of Education and Training (MOET), (7) Ministry of Finance (MOF), (8) Ministry of Foreign Affairs (MOFA), (9) Ministry of Health (MOH), (10) Ministry of Home Affairs (MOHA), (11) Ministry of Industry and Trade (MOIT), (12) Ministry of Justice (MOJ), (13) Ministry of Labor, Invalids and Social Affairs (MOLISA), (14) Ministry of Natural Resources and Environment (MONRE), (15) Ministry of Science and Technology (MOST), (16) Ministry of Transport (MOT), (17) Ministry of Planning and Investment (MPI), and (18) Ministry of Public Security (MPS). The ministeriallevel agencies (MLAs) cover six units: (1) Committee for Ethnic Minority Affairs (CEMA), (2) the Government Office (GO), (3) the State Audit of Vietnam (SAV), (4) the State Bank of Vietnam (SBV), (5) Vietnam General Confederation of Labor (VGCL), and (6) Vietnam Social Security (VSS). The PPCs include all 63 provinces. Vietnam covers 63 provincial units with 61 provinces and two special urban units under central authority, including HCMC and Hanoi capital—equivalent to the provincial level [74,75].

One of the most distinctive features of the COVID-19 policy responses in Vietnam was the mobilization of the whole political system, accepting economic losses in exchange for the safety of people's health and lives, minimizing deaths from the pandemic [76]. As of $24 \mathrm{July}$, all 18 ministries had issued 406/959 documents (42.34\%) and all 63 provincial units throughout the country had announced and implemented their own PDs as well (413/959 documents, accounting for 43.07\%). By 24 July 2020, Vietnam saw CCs in 36 out of 63 provincial units. In Hanoi and HCMC, where the two largest international airports, Noi Bai and Tan Son Nhat, are located, these provincial units had peak numbers of CCs (121 and 62, respectively) as well as the most significant quantities of legal documents (45 and 39, respectively) (see Figure 3 and Figure S3).

\subsubsection{Timing of Policy Responses}

The numbers of PDs were also identified by the five types of agencies (CLs, CFLs, MAs, MLAs, and PPCs) and by period. The multi-level policy approach came from 33 different agencies (from the national to provincial levels), classified in five groups (including $4 \mathrm{CL}$ units, 4 CFL units, 18 MA units, 6 MLA units, and 63 PPC units), in all periods from the beginning days of the outbreak (see Figure 4 and Figure S4).

Figure 5 and Figure S5 illustrate the result of a review of the number of PDs classified by 33 different agencies from the early days of the outbreak to 24 July 2020. The whole process saw 959 COVID-19 PDs released, with 7 in the preparation period, 190 in the first period, 125 in the second, and 357 and 280 in the third and the fourth, respectively, from the central government to the ministry levels and a group of PPCs (including all 63 provincial units nationwide). The PPCs released the greatest number, 314/959 PDs (32.74\%), followed by the $\mathrm{MOH}$ with $138 / 959$ documents (14.39\%), and the MOET and the GO with $8.86 \%$ and $7.51 \%$, respectively (see Figure 5 and Figure S5). One of the findings of La et al.'s study, based on an analysis of COVID-19 news reports in Vietnam from the early days to April 4th, 2020, was that 173 official instructions, guidelines, plans, dispatches, policies, and direct actions were issued by the central government and the relevant ministries [26]. However, our study demonstrates that there were 424 COVID-19 official legal documents, from the central government to the MLs and MLAs, as of April 4th, (see Figure 2), a number 2.45 times higher. With the highest number of PDs in period I from the CLs (15), this analysis demonstrates that the political system of Vietnam put in place strong prevention and control measures from the early days. This extended from the central to local levels throughout the country. 


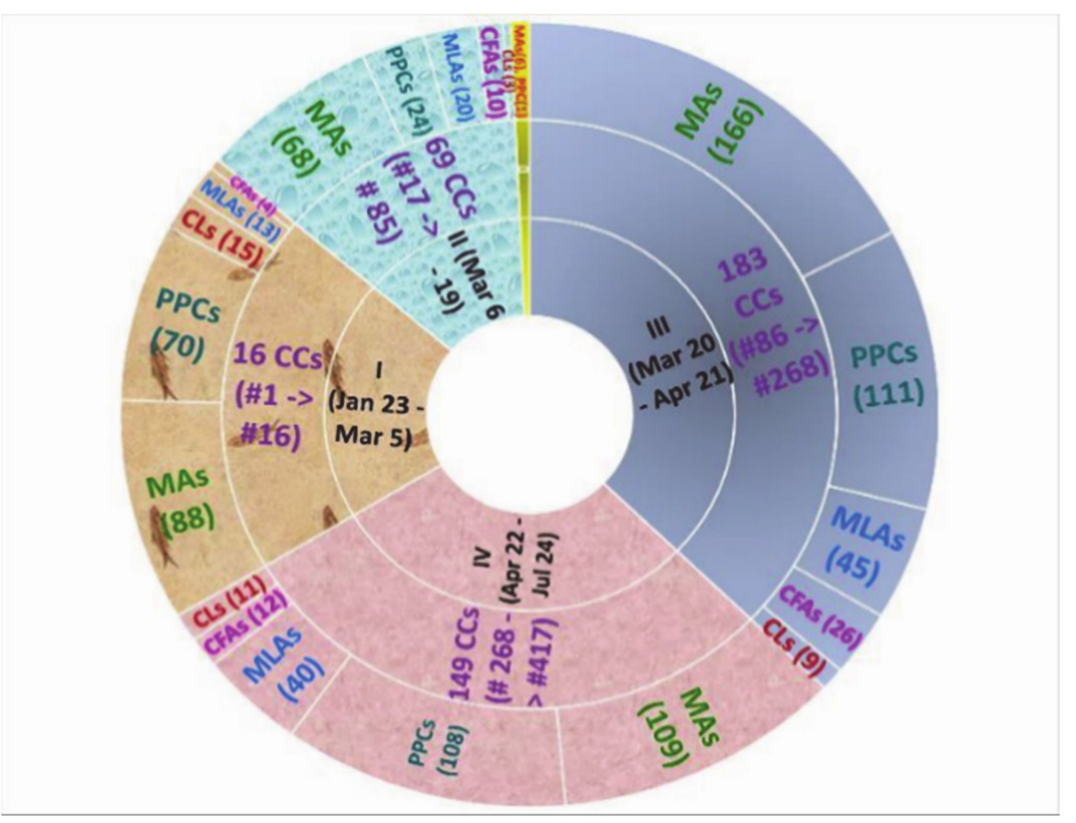

Figure 4. A total of 959 COVID-19 PDs classified by agency groups and timeframe (as of 24 July 2020).

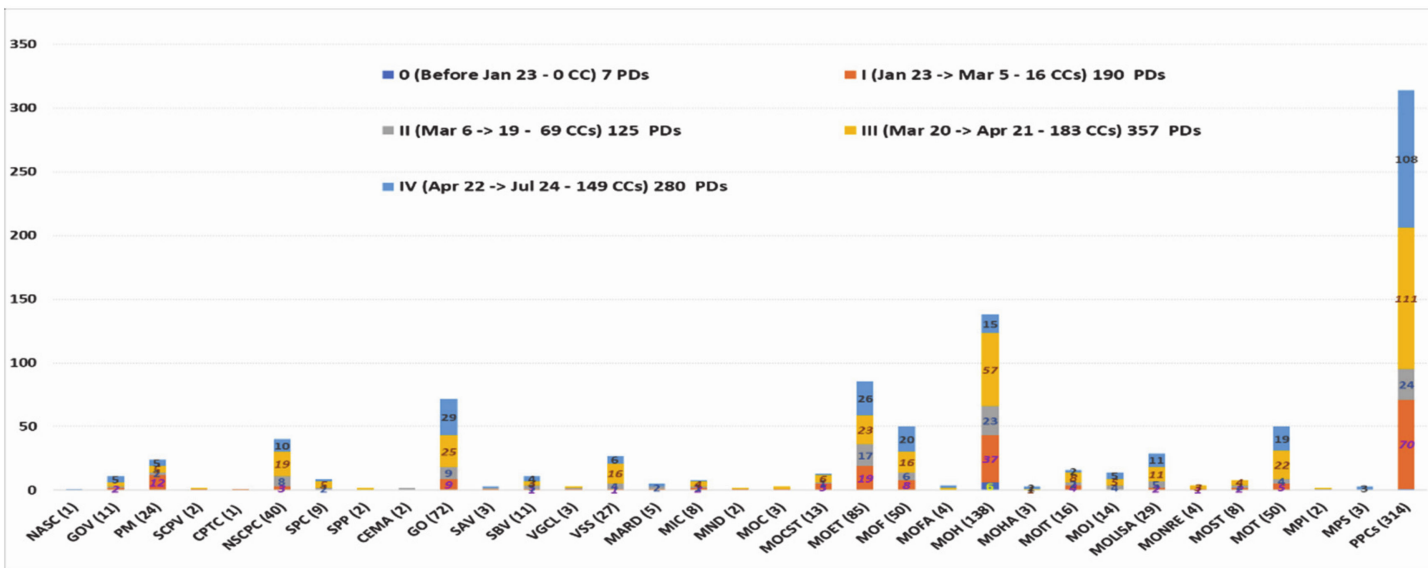

Figure 5. 959 COVID-19 PDs classified by government agencies (as of 24 July 2020).

\subsection{Diversification of Policy Types}

Not only did many government agencies promulgate PDs quickly, but each authority also issued different types of PDs. This study identified nine types of COVID-19 legal documents used in Vietnam as of 24 July 2020 (see Figure 6 and Figure S6), each of which are defined in Appendix A (see Box A1). According to this review, COVID-19 PDs have not been categorized by previous authors.

Of the 959 PDs created during the COVID-19 pandemic in Vietnam up to 24 July, dispatches were the most used policy communication type, with 577 dispatches $(60.17 \%$ of the total \# of documents), followed by 115 decisions (11.99\%), 75 plans (7.82\%), and 74 directives $(7.72 \%)$. Other documents with lower rates included 51 announcements $(5.32 \%), 32$ telegrams $(3.34 \%), 27$ resolutions $(2.82 \%), 5$ circulars $(0.52 \%)$, and 3 guidelines $(0.31 \%)$ (see Figure 6 and Figure S6). 


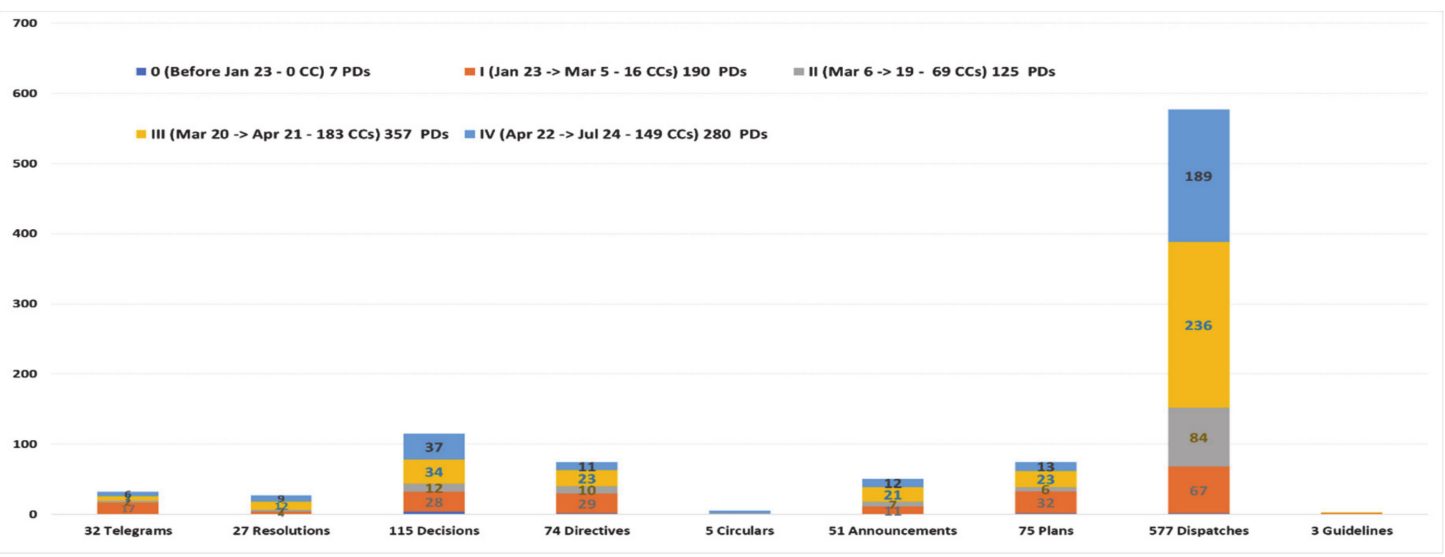

Figure 6. A total of 959 COVID-19 documents classified by policy communication types (as of 24 July 2020).

Analyzing the PD types used by various agencies, dispatches were again the most widely used; $24 / 33$ agencies chose to make their policies known in this way, followed by decisions (14/33), telegrams (12/33), directives (10/33), and announcements $(7 / 33)$. The lowest ranks belonged to circulars and guidelines, with each used only by two agencies (see Figure 7 and Figure S7).

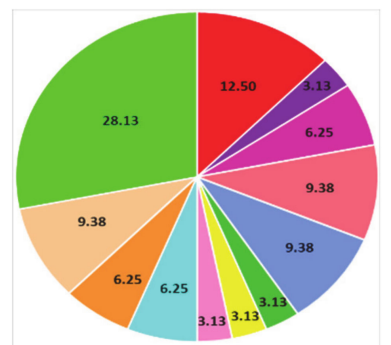

a. \% of telegrams

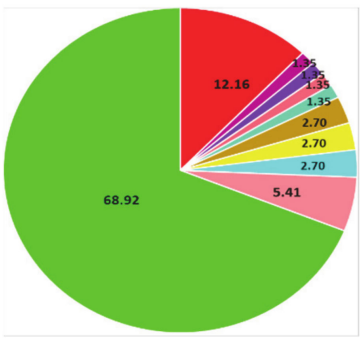

d. $\%$ of directives

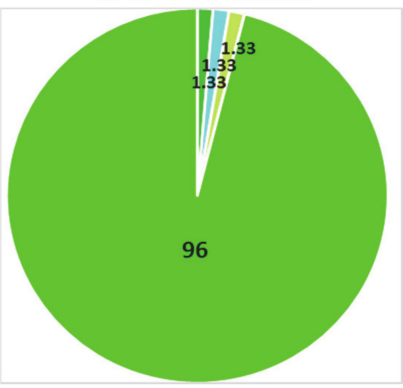

g. \% of plans

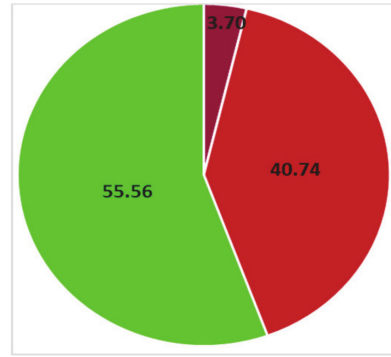

b. $\%$ of resolutions

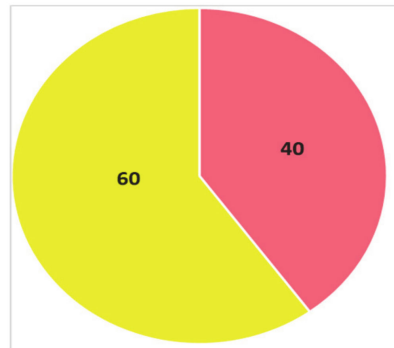

e. $\%$ of circulars

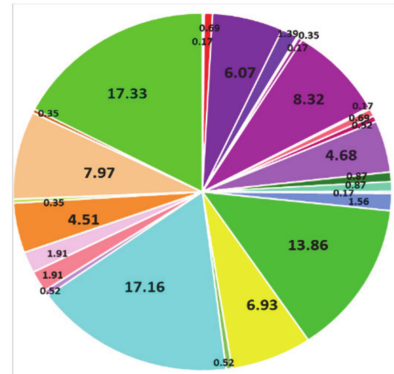

h. $\%$ of dispatches

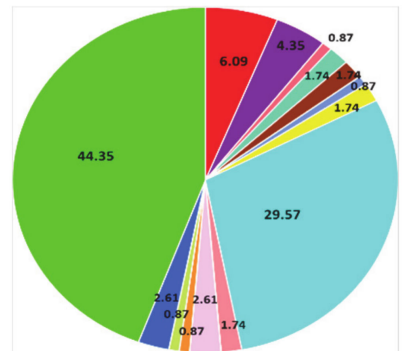

c. $\%$ of decisions

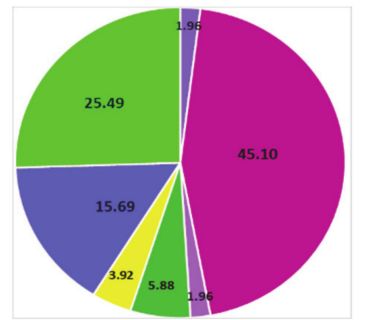

f. \% of announcements

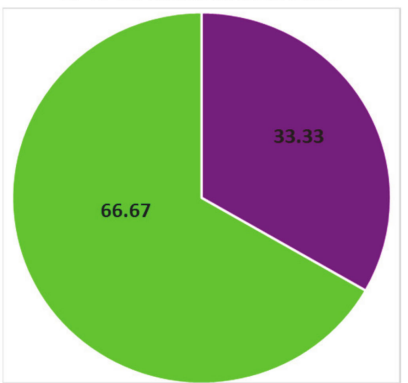

i. $\%$ of guidelines

\begin{tabular}{|c|c|c|c|c|c|c|c|c|c|c|}
\hline NAS & GOV & PM & SCPV & СРTC & C & $\mathrm{SPC}$ & & & GO & \\
\hline SB & VGCL & V & & & & & & & & \\
\hline 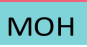 & ИOHA & 00 & & 1OLIS & MONR & $\mathrm{MC}$ & . & & MPS & \\
\hline
\end{tabular}

Figure 7. The proportions of COVID-19 policy forms issued by various agencies in Vietnam (as of 24 July 2020). 
Among the 33 agencies, PPCs (from the 63 provincial units) not only utilized the most diverse range of policy document types (8/9), but in each type (except circulars and announcements) they also accounted for the largest proportion of the communications generated in comparison with the other agencies, from $28.13 \%$ of telegrams to $96 \%$ of plans, as illustrated in Figure 7. The next most diverse set of PDs were released by the MOF, using 6/9 types. The SBV and the MOH each used 5/9 types. Most other authorities issued 2-4 different types, such as the MOET (4/9), the PM, the GO, the NSCPC, the MOCST, and the MOLISA (each using 3/9), and the MOC (2/9) (see Figure 7 and Figure S7).

\subsection{Diversification of Policy Measures}

The policy responses to the COVID-19 emergency have varied between countries and there have been different methodologies used to assess the nature and role of COVID-19 policies across the world. The Blavatnik School of Government at the University of Oxford, for example, has been using a "stringency index" based on seven policy measures to compare countries' differing COVID-19 policies. They include school closings, workplace closings, cancellation of public events, shutting down of public transport, public information campaigns, restrictions on internal movement, and controls on international travel [77]. The School's research focused on 44 countries, but without Vietnam. Another methodology to assess country responses was built by the team at Eurasia Group across three areas: healthcare management, political response, and financial policy response. This study included 11 key countries, again excluding Vietnam: Taiwan, Singapore, South Korea, New Zealand, Australia, Canada, Germany, Iceland, United Arab Emirates, Greece, and Argentina [48].

The COVID-19 policy measures in Vietnam have also attracted the attention of many foreign scholars. In a study of the Exemplars in Global Health platform, Vietnam's emerging COVID-19 success story as of 1 July, 2020, was identified as coming from six policy groups: rapid developed diagnostic test kits; contact tracing; infection prevention and control in healthcare settings; targeted lockdowns; mass gathering, travel, and mobility restrictions; and clear, consistent, creative public health messaging [78]. Some of these findings are similar to those of other scholars $[20,25,79,80]$. Some Vietnamese scholar groups have classified the COVID-19 policy responses in Vietnam according to specific content, such as fake news prevention, assessment of the prevention or of the threat, education, emergency response, market control, national funding, preventive action, reward, social distancing announcement, citizen support, and travel restrictions [26]. The Vietnamese State and the national government have taken 13 key measures to prevent and control the COVID-19 pandemic, including (1) bringing Vietnamese citizens back from the pandemic areas, (2) constructing field hospitals for isolation, (3) utilizing universities' facilities as concentrated isolation zones, (4) keeping all students from schools to limit community contact, (5) issuing bans on crowded meetings and suspending business and entertainment activities for a limited period during the peak period of the pandemic, (6) regularly sending messages via social networks and individuals' mobile phones from the government and the $\mathrm{MOH},(7)$ creating applications on mobile devices to provide information relating to the COVID-19 pandemic, (8) conducting all-people medical declarations related to COVID-19, (9) strict control of entry through border gates, (10) refusing to grant a definite entry visa to foreigners coming to Vietnam, (11) implementing preventive medicine and carrying out disinfection in public places and locations with suspected and infected cases, (12) zoning and quarantining the areas of suspected and infected cases, and (13) calling and encouraging people to voluntarily quarantine when moving from pandemic areas to Vietnam [27].

In this study, eight key overall policy measures were observed, as described in Box 1 and more detail in Appendix B (see Table A1). First, outbreak announcements and steering documents were published promptly and continuously at all different stages of the pandemic $[27,81,82]$. Second, there was a series of medical measures implemented, not only benefiting from experience from the SARS epidemic in 2013 [78] but also applying the $\mathrm{WHO}$ and the MOH's guidance. These measures included various types of medi- 
cal declarations (MDs), from the compulsory level for all people entering the country from 7 March [38,83,84], and even for all people nationwide from 20 March [38,85] to voluntary declarations for all people nationwide from 10 March [86], for all subjects in educational schools and organizations from 26 March [87], and for all domestic travelers from 21 March [88]. Notably, Vietnam was one of the first four countries around the world to culture and successfully isolate the SARS-CoV-2 virus in the early period on 2 February $[81,89,90]$ and produced a detection kit with a capacity of 10,000 sets/day from 4 March [91].

Box 1. Policy measures employed in Vietnam to respond to the COVID-19 pandemic.

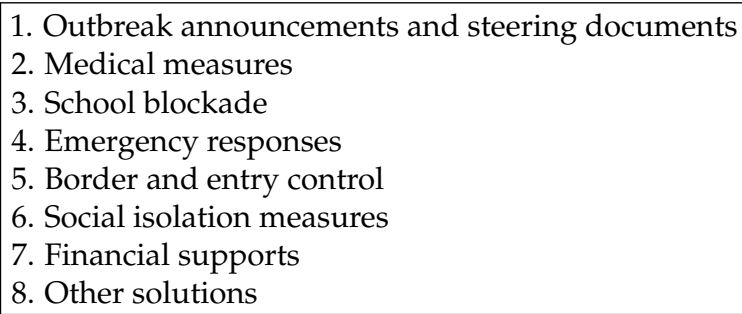

Third, school blockade measures included the students of all 63 provinces nationwide having a significantly longer vacation, from early February to 4 May due to the pandemic (three months, whereas the annual summer vacation usually lasts two months). All schools of all 63 provinces nationwide were closed from 6 February $[9,92-95]$ to the end of April 2020 [96-100]. The MOET also decided to adjust the plan framework twice for the 2019-2020 school year, which delayed the end of the school year and the national high school exam. The second semester program of all general education levels was streamlined to accommodate the extended vacation for the students [82,101]. Fourth, emergency responses such as a series of COVID-19 QRTs established at the ministerial levels for hospitals [9,102-104], and many urgent government meetings from the national to provincial levels were implemented immediately, irrespective of day or night, if any NCs were detected that had moved in the community [44,65,105-112].

Fifth and sixth, Vietnam also conducted other strong measures, including border and entry control $[9,10,45,78,113-117]$ and social isolation in many places such as bars, villages, streets, towns, and cities where sources of infection from the patients were confirmed [10,37,39-41,43,45,94,118-130], and even nationwide social isolation [10,131,132]. For the first time in history, Vietnam thoroughly implemented all models of isolation: compulsory centralized isolation, home isolation, isolation in place, and even nationwide social isolation. This is considered the most effective measure to limit the spread of the outbreak. Not every country applied the same strict quarantines as in Vietnam (such as nationwide social isolation) [82]. As of 7 April, there were $30 \mathrm{PDs}$ issued by the $\mathrm{MOH}$ providing guidance on medical isolation. Tens of thousands of people were sent to concentrated isolation areas (with free support about food, accommodation, medical examination tests, and other living expenses within 14 days, and treatment) $[9,82,133]$.

Seventh, in addition, financial supports from the national government (such VNĐ 62 trillion put in place a social security package to help 20 million domestic people affected by the pandemic [134]) and the practical relief activities came from both the governments and the citizens (including the "rice ATM" [135-137], free supermarket [138-140], etc.) and international communities to make meaningful contributions to the fight against the pandemic in Vietnam. Japan contributed JPY 14 million on 7 February and a test bio-kit worth JPY 4 million on 21 February [141], along with the USA contributing USD 9.5 million [142] and contributions from Korea, France [141]), and others. Finally, a series of other diverse solutions were deployed throughout the country such as strengthening management to avoid collecting and storing goods, advising people about information related to the epidemic through free hotlines and a virtual assistant (chatbot) from the $\mathrm{MOH}$ [9], and the appearance of vivid and varied "spiritual dishes" to foster the anti- 
pandemic universal movement from the boom of music [143-146], to poetry [147-149], films [150,151], etc.

\section{Discussion and Conclusions}

In the current global context, it can be said that no pandemic has had such a profound impact on all aspects of socio-economic life for countries worldwide as COVID-19. Moreover, never in the past have so many unprecedented new policy documents (PDs) been issued widely and continuously in Vietnam to promptly respond to the pandemic [82]. As of 24 July, 2020, Vietnam spent 99 days with no NCs infected from the community [8,9]$365 / 413$ CCs $(88.38 \%)$ recovered and there were zero deaths [6,7]. To have these impressive numbers, the early preparation and immediate policy responses of government levels from national to provincial, as well as the consensus of all strata, were some of the fundamental contributors to the positive outcomes of these timely and effective measures.

It should be noted that similar to Vietnam, other countries in the region such as Mongolia [152], Taiwan, Hong Kong, Singapore, and South Korea also performed effective policy responses in the early stages of the epidemic [48-50]. For example, in Mongolia, the first public preventive measures were introduced by the MOH on 6-12 January, 2020 [152]. Moreover, with the first imported cases on January 13th and January 15th in Thailand and Japan, respectively [153], the Mongolian government immediately held meetings through the $\mathrm{MOH}^{\prime}$ s organization to discuss issues of emergency preparedness regulations and a one-window policy for COVID-19 information from 13-19 January [152]. With rising CCs in China and the appearance of the first CC in South Korea on 20 January, Mongolia issued PDs dated from 20-26 January requiring all educational institutions to be temprarily closed until 30 March and travel restrictions applied to China [152]. In Taiwan, the country established the Enforcement Regulations Governing the Central Epidemics Command Center (Enforcement Regulations-ER, hereafter) in 2004. This is a key component of epidemic preparedness in Taiwan. During each epidemic, with permission from the ER, a Central Epidemic Command Control (CECC) is established by the $\mathrm{MOH}$ and welfare, with the approval of the Executive Yuan to "formulate policies, integrate resources, and coordinate responses across different government ministries and agencies" [154]. The CECC is then dissolved once the commanding official confirms that the threat level is low enough, pending approval from the national government. In the context of COVID-19 in 2019-2020, the CECC in Taiwan was established on 20 January-three days before Wuhan city went into lockdown [154].

Our analysis demonstrated the multidimensional approaches taken from different relevant government levels (33 agencies from 4 levels from central to local, including, most notably, all 18 ministries and all 63 provinces in the country) in issuing various types of PDs (nine tools: resolution, decision, directive, circular, announcement, plan, dispatch, and guideline) as well as a range of policy measures (eight groups: outbreak announcements and steering documents, medical measures, blockading schools, emergency responses, border and entry control measures, social isolation and nationwide social isolation measures, financial supports, and other measures). As a result of these wideranging policy measures and communication tools, issued in a timely manner, the pandemic situation was controlled effectively in the first six months (23 January-24 July). Vietnam's success in the prevention and fight against the pandemic offers significant lessons for other countries [19,20,23-27,78,79,117,155-157].

COVID-19 is at risk of becoming one of the toughest trials for humanity to confront in modern history $[158,159]$. According to Dr. Tedros Adhanom Ghebreyesus, DirectorGeneral of the WHO, COVID-19 is the number one common enemy of humanity, but the actions of many governments and people do not reflect this reality [160]. In the context of much frustration, the policy responses to the COVID-19 pandemic in Vietnam were diverse, proactive, prompt, and widely supported. The proactiveness was not only in legal documents providing guidance before the first two CCs appeared in Vietnam, but also in a series of rapid and drastic larger scale measures that were later deployed synchronously 
and unprecedentedly $[27,81,82]$. The most important factor deciding the success of this fight appears to be the great unanimous force of the integration of the whole society, from authorities of all government levels, security forces, and the military to individuals acting together against the outbreak $[81,161]$. Vietnam is one of the very few countries that mobilized the entire troops, for example, to participate in the pandemic prevention and control from the early days [81]. This mobilization strategy resembles wars that the Communist Party of Vietnam led against the French and American forces in the last century [161]. In particular, the consensus among all classes of people in this war was considered one of the decisive factors in the success [27]. According to one study, Vietnam was the country with the highest satisfaction in the world about the government's responses to the pandemic $(62 \%)[162,163]$ and in another, most of those surveyed thought that the solutions of the Vietnamese government were "efficient" and "very effective" [27]. As a result, the country has been praised by governments and scholars across the globe, and within the Vietnamese population.

The strategy of preventing, detecting, tracing, isolating, localizing, and suppressing the pandemic has been thoroughly applied in Vietnam [78-81,117]. Depending on the specific situation, tactics may change, but the strategy has always been to tighten the defense line for the country against the onslaught of the COVID-19 pandemic [81]. For example, patient CC \#17 was hospitalized on 6 March. Two days later, the Deputy PM Vu Duc Dam declared the second phase of the national outbreak [38]. Similar to the first one, marked by the epidemic declaration, the government escalated its public health response to flatten the curve [45], by applying not only compulsory MDs for all people entering the country $[38,83]$, but also voluntary MDs for all people nationwide from 10 March $[45,86,164]$ the same day as the arrival of CC \#34, who infected 11 other cases and became the most SCC in period II [38]. Then, the appearance of three F0 CCs (\#86, \#87, and \#91) on 20 March marked the beginning of stage III $[45,165,166]$. Instantly, the rule of compulsory MDs was put in place for all people nationwide [38,85], and electronic MDs were requested for all domestic travelers from 21 March [88].

In terms of treatment, Vietnam has built and maintained connections from the front line in the concentrated isolation centers to hospitals through QRTs to share, exchange, and support each other in professional work and treatment regimens that are constantly updated for all infectious generations. The application of science and technology in the pandemic prevention and control was accelerated [81], making Vietnam one of four countries that cultured and successfully isolated the SARS-CoV-2 virus in the early period $[81,89,90]$. The country also conducted research into the production of test kits, proactively produced medical equipment and materials, and promoted the application of information technology in a series of pandemic prevention and control stages (from tracing, following, monitoring, reporting, supporting treatment, etc.) [81]. Vietnam was the first country in the world to apply MDs, and also one of the early adopters of electronic MDs [81].

During the pandemic, special policies on education, health care, and social security have been put in place that did not previously exist. Second, besides "COVID-19," "quarantine" and "isolation" are the most mentioned keywords in Vietnam, with a range of isolation measures put in place. Another highlight is that, despite the economy being seriously affected, the national government has constantly sought to assist all Vietnamese people with the difficulties they are experiencing, so that "no one is left behind" $[82,167,168]$. This included welcoming every Vietnamese to the homeland, even though on the flights many people carried the virus, which was the main cause in increasing the number of CCs [167], and the unprecedented packages of social security support to reduce difficulties for all classes affected by the pandemic [168]. In addition, in the awareness campaigns for pandemic prevention and control, media forces have never participated together so unanimously and drastically as during this time, from the official newspapers and network operators to social networks [81,168]. With the spirit of publicity and transparency $[81,168-171]$, information on steering, prevention, and control recommendations as well as outbreak developments has been conveyed quickly to the public to raise public awareness [81,168]. 
By virtue of these efforts, in the Association of Southeast Asian Nations region, the lockdown measures were lifted first in Vietnam [169] to accomplish a "dual mission": economic development and COVID-19 pandemic prevention [172]. According to the World Bank, Vietnam's economy is well placed to recover after the outbreak if it can identify new growth drivers to reinforce the recovery [169].

In summary, the system of COVID-19 policy responses up to 24 July 2020, were effective to defend against the pandemic in Vietnam. PDs were widely and regularly disseminated, which helped to effectively increase public awareness. Promptly prepared and released PDs provided knowledge and measures for all walks of life to prevent and control the pandemic and protect themselves and others in the community. Although not a rich country, Vietnam has become a model for other countries in the fight against the COVID-19 pandemic, with lessons learned in controlling the spread of the outbreak and for overall responses to a public health crisis $[26,156,168]$.

Supplementary Materials: The following are available online at www.mdpi.com/xxx/s1, Figure S1: Chronology of COVID-19 confirmed cases CCs and numbers of policy documents (PDs) in Vietnam (as of 24 July 2020); Figure S2: Numbers of CCs and PDs released (as of 24 July 2020); Figure S3: Notes for Figure 3; Figure S4: A total of 959 COVID-19 PDs classified by agency groups and timeframe (as of 24 July 2020); Figure S5: 959 COVID-19 PDs classified by government agencies (as of 24 July 2020); Figure S6: A total of 959 COVID-19 documents classified by policy communication types (as of 24 July 2020); Figure S7: The proportions of COVID-19 policy forms issued by various agencies in Vietnam (as of 24 July 2020). Supplementary materials are also available at: https:/ / zenodo.org/record / 4415073.

Author Contributions: T.-A.T.L. and K.V. conceptualized the idea; T.-A.T.L. wrote the first draft; K.V., J.W., G.A., and T.-A.T.L. reviewed and edited the second to the final version. All authors have read and agreed to the published version of the manuscript.

Funding: This research received no external funding.

Institutional Review Board Statement: Not applicable.

Informed Consent Statement: Not applicable.

Data Availability Statement: Not applicable.

Acknowledgments: We would like to thank three anonymous reviewers for their comments, which informed the final version of this manuscript. The authors also would like to dedicate this research to Vietnam, to the Vietnamese government, to all the brave and kind healthcare workers, and to all other Vietnamese people and international supports, as well for the all efforts conducted together in the fight against the COVID-19 pandemic. We hope that the entirety of humanity will overcome this crisis time soon.

Conflicts of Interest: The authors declare no conflict of interest. 


\section{Appendix A}

Box A1. Definitions of nine PD communication tools.

A "telegram" is a news item transmitted by electrical signals [173], sent by a state agency or government officials to relevant agencies
or organizations on matters arising in special circumstances. The special circumstances may lead to the need to apply emergency
measures to limit damage caused by natural disasters, prevent and control epidemics, or protect sovereignty, territorial integrity,
political security, and social order [174].
A "resolution" is a form of legal document promulgated by the National Assembly, the government, and the PCs at all levels. A
resolution is also a kind of document made by socio-political organizations, social organizations, and unions on issues of their
activities [175].
A "decision" is a legal document used to promulgate specific measures and regulations to implement the Party and State's guidelines
and policies issued by agencies and individuals to solve daily tasks of organizations and agencies [176].
A "directive" is a form of legal document from the PM or the PCs at all levels to concretize and direct the implementation of the
constitution, laws, ordinances, orders, resolutions, decrees, and decisions of state agencies promulgated under the provisions of law
for subordinates to implement [177].
A "circular" is a form of legal document to explain and guide the implementation of documents issued by the State or MA(s) or
MLA(s), under the management of a certain field or department [178,179].
An "announcement" is a form of common administrative documents used to convey the content of a decision, provide news to
agencies and individuals, and introduce a policy that has not been institutionalized in writing [180].
A "plan" is all the things that are intended to be done, including many systematic arrangements, assigned to a certain purpose and
done in a predetermined time [181].
A "dispatch" is a form of document sent from one public authority to another, including between higher and lower levels or vice
versa, to solve public mission issues between state agencies [182].
A "guideline" is a form of administrative document including specific processes and rules issued by authorities to subordinates to
implement an action process to achieve the set plan or goals.

\section{Appendix B}

Table A1. The overall policy measures to cope with the COVID-19 pandemic in Vietnam (as of 24 July 2020).

\begin{tabular}{|c|c|c|c|c|}
\hline Mea & $\begin{array}{l}\text { Period I } \\
\text { (23 January-5 March): } \\
16 \text { CCs and } 190 \text { PDs }\end{array}$ & $\begin{array}{l}\text { Period II (6-19 March): } \\
69 \text { CCs and } 125 \text { PDs }\end{array}$ & $\begin{array}{l}\text { Period III } \\
\text { (20 March-21 April): } \\
183 \text { CCs and } 357 \text { PDs }\end{array}$ & $\begin{array}{l}\text { Period IV } \\
\text { (22 April-24 July): } \\
149 \text { CCs and } 280 \text { PDs }\end{array}$ \\
\hline
\end{tabular}

The outbreak in Vietnam was declared on 23 January in telegraph 121/PM after the first 2 Chinese CCs [183]; The international emergency outbreak was proclaimed on 30 January by the WHO $[184,185]$, and the NSCPC was established on the same day after the

(1) Outbreak announcements and steering documents first 3 Vietnamese CCs, \#3-\#5, who returned from Wuhan $[36,186,187]$. One day later, directive 06/PM on strengthening the prevention and control measures was issued [9]. The national epidemic was declared on 1 February in decision 173/PM due to CC \#6 infected from \#1 [10,58,108].
The first SCC in Vietnam, CC\#17, was published on 6 March $[38,188]$. The 2nd period of the outbreak was declared on 8 March [38]. COVID-19 as a global pandemic was declared on 11 March by the WHO [187] [189]. This hot news, in Vietnam, immediately the next day, was released on many official channels [190-194]
Period III was declared on 23 March by the PM [165] after 3 CCs (\#86, \#87, and \#91) appeared on 20 March $[45,166]$. Period III became the most complex phase of the pandemic in Vietnam in directive No. 15/PM dated on 27 March [195].

Social distancing and social isolation were officially applied throughout the country from 31 March according to directive No. 16/PM [196].

Announcement of the nationwide pandemic on 1 April appeared in decision No. 447/PM [197].
"Dual mission": both economic development and COVID-19 pandemic prevention [172]. 
Table A1. Cont.

\begin{tabular}{|c|c|c|c|c|}
\hline Measure & $\begin{array}{l}\text { Period I } \\
\text { (23 January-5 March): } \\
16 \text { CCs and } 190 \text { PDs }\end{array}$ & $\begin{array}{l}\text { Period II (6-19 March): } \\
69 \text { CCs and } 125 \text { PDs }\end{array}$ & $\begin{array}{l}\text { Period III } \\
\text { (20 March-21 April): } \\
183 \text { CCs and } 357 \text { PDs }\end{array}$ & $\begin{array}{l}\text { Period IV } \\
\text { (22 April-24 July): } \\
149 \text { CCs and } 280 \text { PDs }\end{array}$ \\
\hline (2) Medical measures & $\begin{array}{l}\text { Treatment regimens } \\
\text { constantly updated from } \\
\text { the WHO's guidance and } \\
\text { inherited experience } \\
\text { from the SARS epidemic } \\
\text { in } 2013 \text { [78] to provide } \\
\text { specific treatment } \\
\text { strategies for } \\
\text { each patient [198], as of } \\
25 \text { February, all first } \\
16 \text { CCs recovered and } \\
\text { discharged [199]. } \\
\text { Isolating and raising new } \\
\text { strain of corona virus } \\
\text { successfully in Vietnam } \\
\text { on } 2 \text { February [81,89,90]. } \\
\text { Vietnam manufactured } \\
\text { Sars-Cov-2 detection kit } \\
\text { with capacity of } \\
10,000 \text { sets/day from } \\
4 \text { March [91]. }\end{array}$ & $\begin{array}{l}\text { Compulsory medical } \\
\text { declaration (MD) for all } \\
\text { people entering the } \\
\text { country from } \\
7 \text { March [38,83,84], } \\
\text { voluntary MD for all } \\
\text { people nationwide } \\
\text { from } 10 \text { March [86]. } \\
2 \text { mobile applications } \\
\text { "NCOVI" and } \\
\text { "Vietnam MD”) } \\
\text { introduced by the } \\
\text { MOH and the MIC on } \\
10 \text { March [45,164] after } \\
\text { CC \#34 on the same } \\
\text { day-the most SCC in } \\
\text { period II, who infected } \\
11 \text { others [37]. } \\
\text { The detection kit of } \\
\text { Vietnam ordered to buy } \\
\text { by } 20 \text { foreign countries } \\
\text { as of Mar } 17 \text { [200,201], } \\
\text { and exported to the } \\
\text { first } 4 \text { countries: } \\
\text { Malaysia, Iran, Finland } \\
\text { and Ukraine [201]. }\end{array}$ & $\begin{array}{l}\text { Compulsory MD for all } \\
\text { people nationwide from } \\
20 \text { March according to } \\
\text { dipatch No.1436/ } \\
\text { NSCPC [38,85]; } \\
\text { Electronic MD applied } \\
\text { for all domestic travelers } \\
\text { from } 21 \text { March [88]; } \\
\text { Voluntary MD in } \\
\text { education area for the all } \\
2.4 \text { million pupils, } \\
\text { students and 1.5 million } \\
\text { teachers from } \\
26 \text { March [87]. } \\
10 \text { field testing stations } \\
\text { deployed throughout } \\
\text { Hanoi from 31 March } \\
\text { after Bach Mai outbreak } \\
28 \text { March [10,202]. } \\
\text { Vietnam recorded and } \\
\text { isolated successfully two } \\
\text { in three different } \\
\text { SARS-CoV-2 viruses as of } \\
\text { early April [90,203]. } \\
\text { A successful study of } \\
\text { antibody testing method } \\
\text { (rapid test) announced } \\
\text { on } 27 \text { April [204]. }\end{array}$ & $\begin{array}{l}\text { The Vietnamese } \\
\text { COVID-19 test kit } \\
\text { approved by WHO } \\
\text { and Social Care of the } \\
\text { UK as of } \\
21 \text { April [205]. } \\
20,000 \text { COVID-19 test } \\
\text { kits of Vietnam } \\
\text { exported to } 8 \\
\text { countries as of } \\
22 \text { May [206]. }\end{array}$ \\
\hline (3) School blockade & $\begin{array}{l}\text { Students of all } \\
63 \text { provinces left schools } \\
\text { as of } 6 \text { February } \\
\text { according to the telegram } \\
\text { No. } 156 / \text { PM and } \\
\text { dispatch } \\
\text { No. } 716 / \text { GO [9,92-95]. }\end{array}$ & $\begin{array}{l}\text { The students' vacation } \\
\text { extended until the end } \\
\text { of March, or early April } \\
\text { in } 27 / 63 \text { provinces as } \\
\text { of } 13 \text { March due to the } \\
\text { pandemic [207]. }\end{array}$ & $\begin{array}{l}\text { All school operations } \\
\text { nationwide closed to the } \\
\text { end of April, } \\
2020 \text { [96-100]. }\end{array}$ & $\begin{array}{l}\text { Students of } 7 / 63 \\
\text { provinces returned } \\
\text { the schools from } \\
\text { 20-24 April [9]. } \\
\text { More 30/63 provinces } \\
\text { reopened the schools } \\
\text { on } 27 \text { April [9]. }\end{array}$ \\
\hline $\begin{array}{l}\text { (4) Emergency } \\
\text { responses }\end{array}$ & $\begin{array}{l}\text { An urgent meeting was } \\
\text { held in Hanoi on } \\
23 \text { January when the } \\
\text { epidemic spreading in } \\
\text { Korea, Japan [208]; A } \\
\text { series of COVID-19 QRTs } \\
\text { established: 25 QRTs of } \\
\text { the MOH and 20 QRTs of } \\
\text { the MOD (23-31 January); } \\
\text { 31/47 central public } \\
\text { hospitals (45 QRTs) and } \\
\text { all provincial hospitals } \\
\text { (1-2 QRTs/hospital) on } \\
\text { February [9,102-104]. } \\
\text { Close and urgent } \\
\text { coordination between } \\
\text { stakeholders, such } \\
\text { among 21 hospitals, the } \\
\text { MOH and the } \\
\text { MOD [9,154]. }\end{array}$ & $\begin{array}{l}\text { Night of } 6 \text { March and } \\
7 \text { March: urgent } \\
\text { meetings in Hanoi } \\
\text { about CC \#17-the first } \\
\text { case in Hanoi and } \\
\text { discussing the timely } \\
\text { solutions }[105,107] .\end{array}$ & $\begin{array}{l}\text { The most provincial } \\
\text { emergency meetings } \\
\text { were carried out (after } \\
\text { each complicated CC } \\
\text { announced) such in Thai } \\
\text { Nguyen on } 28 \text { March } \\
\text { (due to Bach Mai } \\
\text { hospital's outbreak); } \\
\text { Lai Chau on } 24 \text { March; } \\
\text { Hanoi, Dong Nai and Ha } \\
\text { Nam on } 7 \text { April } \\
\text { due to CCs \#133, \#243, } \\
\text { \#247 and \#251, } \\
\text { respectively [106,108-111]; } \\
2 \text { urgent dispatches at } \\
\text { midnight } 28 \text { March to } \\
\text { prevent the SCCs issued } \\
\text { by Hanoi PC because of } \\
\text { Bach Mai-the hottest } \\
\text { outbreak [209]. }\end{array}$ & $\begin{array}{l}\text { An emergency } \\
\text { meeting in Ha Giang } \\
\text { province on } 16 \text { April } \\
\text { to quarantine } \\
2 \text { communes, } \\
2 \text { hospitals, and to } \\
\text { block } 1 \text { village (in } \\
\text { Dong Van district) } \\
\text { related to CC } \\
\text { \#268 [112]. }\end{array}$ \\
\hline
\end{tabular}


Table A1. Cont.

\begin{tabular}{|c|c|c|c|c|}
\hline Measure & $\begin{array}{l}\text { Period I } \\
\text { (23 January-5 March): } \\
16 \text { CCs and } 190 \text { PDs }\end{array}$ & $\begin{array}{l}\text { Period II (6-19 March): } \\
69 \text { CCs and } 125 \text { PDs }\end{array}$ & $\begin{array}{l}\text { Period III } \\
\text { (20 March-21 April): } \\
183 \text { CCs and } 357 \text { PDs }\end{array}$ & $\begin{array}{l}\text { Period IV } \\
\text { (22 April-24 July): } \\
149 \text { CCs and } 280 \text { PDs }\end{array}$ \\
\hline $\begin{array}{l}\text { (5) Border and } \\
\text { entry control } \\
\text { measures }\end{array}$ & $\begin{array}{l}\text { All flights from } \\
\text { Wuhan canceled from } \\
\text { 23 January [9]. } \\
\text { The national borders } \\
\text { with China tightened } \\
\text { and visa issuance } \\
\text { restricted for } \\
\text { foreigners from } 31 \\
\text { January according } \\
\text { to directive } \\
\text { No. 06/PM [10]. } \\
\text { More rules to tighten } \\
\text { borders, revoke } \\
\text { aviation licenses and } \\
\text { restrict visas from } \\
1 \text { February due to } \\
\text { decision No. 173/PM } \\
\text { after CC \#6-the } \\
\text { first case infected } \\
\text { from the local } \\
\text { community [113]. }\end{array}$ & $\begin{array}{l}\text { Visas for EU stopped; } \\
\text { flights minimized, } \\
\text { tourism managed strictly, } \\
\text { delegations going to } \\
\text { work abroad } \\
\text { postponed from } 11 \text { March } \\
\text { according to directive No. } \\
\text { 13/PM [114]. 14-day } \\
\text { mandatory isolation in } \\
\text { quarantine centers for all } \\
\text { passengers who traveled } \\
\text { through } 59 \text { epidemic } \\
\text { countries [115]. } \\
\text { Thousands of Vietnamese } \\
\text { people rushed home } \\
\text { every day from foreign } \\
\text { pandemic zones, only in } \\
\text { 18 March, nearly } 7000 \\
\text { Vietnamese people } \\
\text { returned home and } \\
\text { quarantined from the } \\
\text { airports [210,211]; all } \\
\text { international routes } \\
\text { suspended from 19 } \\
\text { March-30 April [116]. }\end{array}$ & $\begin{array}{l}\text { Foreign entry suspended, } \\
\text { and all exceptions, } \\
\text { including national } \\
\text { returnees, had to be } \\
\text { implemented mandatory } \\
\text { medical tests and 14-day } \\
\text { quarantine from } \\
22 \text { March [45]. }\end{array}$ & $\begin{array}{l}\text { Reopening domestic } \\
\text { routes: The first } \\
\text { commercial flight from } \\
\text { Tan Son Nhat } \\
\text { international airport (of } \\
\text { HCMC) to Van Don } \\
\text { airport (Quang Ninh } \\
\text { province) on } 4 \text { May } \\
\text { implemented after } \\
\text { COVID-19 } \\
\text { interruption [212]; the } \\
\text { airlines back to the sky } \\
\text { from } 23 \text { April and from } \\
1 \text { June, the entire } \\
\text { domestic flight network } \\
\text { allowed to exploit [213]. } \\
\text { Reopening international } \\
\text { routes: Vietnam Airlines } \\
\text { flew its first international } \\
\text { flight to China on 18 July, } \\
\text { after more than } 5 \text { months } \\
\text { of the pandemic with all } \\
270 \text { Chinese } \\
\text { passengers [214]. }\end{array}$ \\
\hline
\end{tabular}

Blockade for in-place isolation: 190 people of all households (HHs) from number 125 to 139 established at the (6) Social isolatio and nationwide social isolation measures
All festivals canceled in the epidemic provinces from 2 February as a result of telegram No. 156/PM [94]. The first mandatory isolation center 123rd regiment (3 February) in Lang Son province to receive more than 400 Vietnamese people from China

Truc Bach street where CC \#17's HH living (6-20 March) $[10,37,45,130]$; 2 routes (Hoang Van Thu and Ngo Sy Lien) of Phan Thiet city where CC \#38 living with 150 people (CC \#38 - the first case in Binh Thuan province-infected from CC \#34) (13 March-3 April) [10,118]; all 900 HHs, 5600 people of Van Lam 3 village (Phuoc Nam commune, Thuan and isolated them for Nam district) where CCs 14 days [10].

Blockade for in-place isolation: with $11 \mathrm{CCs}$ in Son Loi commune (of Binh Xuyen district, Vinh Phuc province), nearly 11,000 people in the whole commune cordoned off-the first quarantined locality in its place (13 February-4 March) [10,37,129].
The contagious places closed, such Buddha bar-the biggest infectious place in HCMC due to some CCs related to here (\#91, \#133, etc) on 21 March [39-41]; Gia Dinh shoes company on 24 March because of many workers here contacting with CC \#124-one SCC [43]. Blockade for in-place isolation: 2 locations of Lai Chau city-area of CC \#133's HH living (24 March-21 April) [124]; Bach Mai hospital-the most complex outbreak in Vietnam with more than 10 CCs (28 March10 April) $[45,125,126]$ and $\mathrm{Ha}$ Loi village (of Me Linh district) due to $\mathrm{CC}$ \#243-one SCC (7-30 April) [10].

Messages were sent to 18,000 the relevant people who had been to Bach Mai hospital since 12 March to request quarantine as of 30

March [127].

The whole Vietnamese society quarantined within 15 days from Apr 1 according to directive

No. 16/PM [10,131,132].
Blockade for in-place isolation: the whole Dong Van town (Ha Giang province) with $1629 \mathrm{HHs}$, equivalent to 7623 people from 22 April due to CC \#268 [128]. Pandemic prevention integrated with economic recovery: Social isolation basically stopped nationwide from 23 April, except for some high-risk areas in Hanoi, Ha Giang and Bac Ninh. Some activities were still required to be completely banned such festivals, crowded sports events, facility operations discotheque, karaoke, massage, makeup, flower shop, zoo, etc [215]. In Hanoi, where having the most CCs in the country, except for Me Linh and Thuong Tin districts, other districts stopped social isolation, many socio- economic activities gradually resumed [216]. than 62,000 Vietnamese and foreigners from the pandemic zones, as of 19 March [165]. 
Table A1. Cont.

\begin{tabular}{|c|c|c|c|c|}
\hline Measure & $\begin{array}{l}\text { Period I } \\
\text { (23 January-5 March): } \\
16 \text { CCs and } 190 \text { PDs }\end{array}$ & $\begin{array}{l}\text { Period II (6-19 March): } \\
69 \text { CCs and } 125 \text { PDs }\end{array}$ & $\begin{array}{l}\text { Period III } \\
\text { (20 March-21 April): } \\
183 \text { CCs and } 357 \text { PDs }\end{array}$ & $\begin{array}{l}\text { Period IV } \\
\text { (22 April-24 July): } \\
149 \text { CCs and } 280 \text { PDs }\end{array}$ \\
\hline (7) Financial supports & $\begin{array}{l}\text { Free amenities for } \\
\text { quarantined people: } \\
\text { exempting from } \\
\text { medical examination } \\
\text { and treatment } \\
\text { expenses; granted free } \\
\text { of charge with drinking } \\
\text { water, face towels, face } \\
\text { masks, water for hand } \\
\text { sanitizers, oral } \\
\text { disinfectants, } \\
\text { toothbrushes, bath soap } \\
\text { and other essential } \\
\text { items serving daily } \\
\text { needs and free in } \\
\text { moving to quarantine } \\
\text { centers [217]; } \\
\text { International supports: } \\
\text { from Japan } \\
\text { (JP ¥14 million on } 7 \\
\text { February; test bio-kit } \\
\text { worth JP ¥4 million on } \\
21 \text { February) [141]. }\end{array}$ & $\begin{array}{l}\text { Funding for } \\
\text { COVID-19 screening } \\
\text { exams, such as VND } \\
3.5 \text { billion provided } \\
\text { on } 11 \text { March by } \\
\text { Hanoi PC [9]. } \\
\text { Official information } \\
\text { of the waiver of the } \\
\text { full treatment fee for } \\
\text { all CCs and all people } \\
\text { isolated in the } \\
\text { quarantine centers } \\
\text { and at home } \\
\text { published on } 13 \\
\text { March [9]. }\end{array}$ & $\begin{array}{l}\text { A letter calling for all } \\
\text { people to support the } \\
\text { fight against the } \\
\text { pandemic was issued by } \\
\text { the national government } \\
\text { on } 17 \text { March. Up to this } \\
\text { time, more than } 30 \text { units } \\
\text { were supported with } \\
\text { VND } 235 \text { billion [218]. } \\
\text { Domestic supports: over } \\
\text { VND } 33 \text { billion from } \\
\text { some famous people as } \\
\text { of } 20 \text { March; on } 3 \text { April, } \\
\text { Vingroup-one of the } \\
\text { largest multidisciplinary } \\
\text { private economic groups } \\
\text { in Asia-located in } \\
\text { Vietnam [219], } \\
\text { committed to donate to } \\
\text { the MOH 5,000 } \\
\text { ventilators [220]; as of } 9 \\
\text { April, } 2.2 \text { million support } \\
\text { messages (equivalent to } \\
\text { VND133 billion) [221]. } \\
\text { International supports: } \\
\text { from Japan (more than JP } \\
¥ 200 \text { million, medical } \\
\text { technologies and } 50.000 \\
\text { face masks as of } 9 \text { April), } \\
\text { the USA (USD 4.5 million } \\
\text { as of } 16 \text { April [141]. } \\
\text { “Rice ATM": The first rice } \\
\text { ATM was operated in } \\
\text { HCMC on } 6 \text { April [135], } \\
\text { then it was replicated } \\
\text { in many other } \\
\text { provinces [136,137]. } \\
\text { A VND 62,000 billion } \\
\text { social security package } \\
\text { was mentioned in } \\
\text { Resolution No. } 42 / G O V \\
\text { on } 9 \text { April [222]. } \\
\text { Electricity price reduced } \\
\text { from Apr to } \\
\text { Jun } 2020 \text { [198]. }\end{array}$ & $\begin{array}{l}\text { A VND } 62 \text { trillion } \\
\text { social security package } \\
\text { was officially approved } \\
\text { in decision No. 15/PM } \\
\text { on } 24 \text { April with the } \\
\text { recipients including } \\
\text { employees in all } \\
63 \text { provinces who } \\
\text { postponed the } \\
\text { performance of labor } \\
\text { contracts and took } \\
\text { leave without pay for } \\
\text { at least } 1 \text { month, } \\
\text { enterprises without } \\
\text { revenue/financial } \\
\text { resources to pay wages, } \\
\text { employers, individual } \\
\text { business households } \\
\text { and many other social } \\
\text { objects such the poor, } \\
\text { people with } \\
\text { meritorious services to } \\
\text { the revolution [134]. } \\
\text { International supports: } \\
\text { from the USA, USD } \\
9.5 \text { million, including } \\
\text { USD } 5 \text { million for } \\
\text { economic assistance } \\
\text { funds and USD } \\
4.5 \text { million medical } \\
\text { assistance-according } \\
\text { to announcement of the } \\
\text { US Department of State } \\
\text { on } 1 \text { May [142], and } \\
\text { support from Korea } \\
\text { and France [141]. } \\
\text { Free supermarket: The } \\
\text { first VND zero } \\
\text { supermarket in HCMC } \\
\text { was established to } \\
\text { support the poor on } \\
21 \text { April [138], then it } \\
\text { spread to many other } \\
\text { provinces [139,140]. }\end{array}$ \\
\hline
\end{tabular}


Table A1. Cont.

\begin{tabular}{|c|c|c|c|c|}
\hline Measure & $\begin{array}{l}\text { Period I } \\
\text { (23 January-5 March): } \\
16 \text { CCs and } 190 \text { PDs }\end{array}$ & $\begin{array}{l}\text { Period II (6-19 March): } \\
69 \text { CCs and } 125 \text { PDs }\end{array}$ & $\begin{array}{l}\text { Period III } \\
\text { (20 March-21 April): } \\
183 \text { CCs and } 357 \text { PDs }\end{array}$ & $\begin{array}{l}\text { Period IV } \\
\text { (22 April-24 July): } \\
149 \text { CCs and } 280 \text { PDs }\end{array}$ \\
\hline (8) Other measures & $\begin{array}{l}\text { Management was } \\
\text { strengthened to avoid } \\
\text { collecting and storing } \\
\text { goods from } 31 \text { January [9]. } \\
\text { People were advised about } \\
\text { information related } \\
\text { through } 2 \text { free hotline } \\
\text { numbers, } 19003228 \text { (from } \\
\text { 31 January) and } 19009095 \\
\text { (from } 2 \text { February) and a } \\
\text { virtual assistant (chatbot) } \\
\text { at https:/ /ehealth.gov.vn } \\
\text { of the MOH (from 14 } \\
\text { February) [9]; Handling } \\
\text { violations: } 1136 \text { cases of } \\
\text { price violations at medical } \\
\text { equipment stores and } \\
\text { drugstores nationwide } \\
\text { handled, as of } \\
2 \text { February [9]; Military } \\
\text { rehearsal in the whole } \\
\text { army: more than } 220 \\
\text { nationwide military units } \\
\text { conducted drills to prevent } \\
\text { and control the epidemic } \\
\text { with } 5 \text { scenarios (the 5th } \\
\text { level scenario } \\
3,000-30,000 \text { CCs) in the } \\
\text { form of online on } \\
4 \text { March [223]. An } \\
\text { abundance of media } \\
\text { products in the form of } \\
\text { music launched to raise } \\
\text { awareness of disease } \\
\text { prevention, such } \\
\text { appearance of many } \\
\text { COVID-19 songs, in which } \\
\text { “Ghen Cô Vy" (published } \\
\text { on } 23 \text { February) came } \\
\text { out-the hottest } \\
\text { phenomenon } \\
\text { spreading around } \\
\text { the world [143-146]. } \\
\text { The movement of } \\
\text { composing poetry to } \\
\text { prevent pandemics } \\
\text { exploded strongly in all } \\
\text { classes of people [147-149]. }\end{array}$ & $\begin{array}{l}\text { "Jealous Coronavirus" } \\
\text { song was voted in the } \\
\text { top } 10 \text { of the panic } \\
\text { reduction of COVID-19 } \\
\text { season on } 9 \text { March by } \\
\text { Billboard music } \\
\text { magazine [224,225]. } \\
\text { The original version } \\
\text { spread the addition of } \\
\text { subtitles in over } \\
25 \text { languages, as of } \\
17 \text { March [226,227]. } \\
\text { Cases of posting false } \\
\text { information were } \\
\text { penalized: } 21 \text { cases of } \\
\text { posting untrue } \\
\text { information on social } \\
\text { networks related to the } \\
\text { epidemic were } \\
\text { penalized, as of } \\
10 \text { March [228]; } \\
\text { Everyone must strictly } \\
\text { wear masks in public } \\
\text { places from } 16 \text { March } \\
\text { according to } \\
\text { announcement No. } 98 \\
\text { of the GOV [37,229,230] } \\
\text { and Dispatch No. } \\
1360 / \text { MOH [231]. }\end{array}$ & $\begin{array}{l}\text { Release of COVID } \\
\text { TV-series: "The } \\
\text { Unforgettable Days" } \\
\text { with } 50 \text { episodes } \\
\text { ( } 25 \text { minutes/episode) } \\
\text { screened in the golden } \\
\text { hour time (21 p.m.) } \\
\text { from Monday to Friday } \\
\text { weekly, from } 6 \text { April on } \\
\text { VTV1 channel-one of } \\
\text { the national channels } \\
\text { with the most } \\
\text { audiences, about } \\
\text { propaganda of the } \\
\text { pandemic theme } \\
\text { integrated with } \\
\text { entertainment } \\
\text { factors [150,151]. } \\
\text { According to our } \\
\text { finding, it rated around } \\
\text { 200,000 views after } \\
3-5 \text { days of uploading } \\
\text { each episode to } \\
\text { YouTube. } \\
\text { Many meaningful new } \\
\text { COVID-19 songs were } \\
\text { performed to } \\
\text { contribute to repel the } \\
\text { pandemic [232]; of } \\
\text { which English versions } \\
\text { of "Jealous } \\
\text { Coronavius"and } \\
\text { “Washing hand song" } \\
\text { were released on } \\
9 \text { April [233]; as of } \\
12 \text { April, over } \\
100 \text { domestic } \\
\text { COVID-19 songs were } \\
\text { created, } 60 \text { of which } \\
\text { were selected in the } \\
\text { book "Belief" [234]. }\end{array}$ & $\begin{array}{l}\text { Strict penalties for } \\
\text { violations of senior } \\
\text { officials: on } 22 \text { April, } \\
\text { Mr. Nguyen Nhat } \\
\text { Cam-director of the } \\
\text { Hanoi Center for } \\
\text { Disease Control } \\
\text { (CDC)-was prosecuted } \\
\text { and arrested in } \\
\text { detention to investigate } \\
\text { the price increase in the } \\
\text { process of purchasing } \\
\text { COVID-19 testing } \\
\text { machines [235]. On } \\
7 \text { July, two more CDC } \\
\text { Hanoi managers were } \\
\text { also prosecuted due to } \\
\text { the same } \\
\text { violation [236]. }\end{array}$ \\
\hline
\end{tabular}




\section{References}

1. WHO. Archived: WHO Timeline-COVID-19. Available online: https://www.who.int/news-room/detail/27-04-2020-whotimeline---covid-19 (accessed on 8 August 2020).

2. ecdc.europa.eu Update: Cluster of Pneumonia Cases Associated with Novel Coronavirus—Wuhan, China-2019. Available online: https: / / www.ecdc.europa.eu/en/news-events/update-cluster-pneumonia-cases-associated-novel-coronavirus-wuhanchina-2019 (accessed on 28 August 2020).

3. WHO. WHO Coronavirus Disease (COVID-19) Dashboard. Available online: https:// covid19.who.int/?gclid=CjwKCAjwmrn5BRB2 EiwAZgL9ouUtJQ4gTwmDKGVinoCIY5rb3ztTsocbiMLnRIEjbL3boMBrpwImKxoCEt4QAvD_BwE (accessed on 8 August 2020).

4. Neustaeter, B.; WHO. Reports Two Highest Daily Coronavirus Case Counts Ever. Available online: https://www.ctvnews.ca/ health/coronavirus/who-reports-two-highest-daily-coronavirus-case-counts-ever-1.5039501 (accessed on 28 August 2020).

5. cbc.ca Coronavirus: What's Happening Around the World on 24 July. Available online: https://www.cbc.ca/news/world/ coronavirus-july-24-covid-19-1.5661448 (accessed on 28 August 2020).

6. MOH Bộ Y Tế, trang tin về dịch bệnh viêm đường hô hấp cấp COVID-19 (Ministry of Health, News Site on Acute Respiratory Infections COVID-19). Available online: https://ncov.moh.gov.vn/web/guest/trang-chu (accessed on 9 August 2020).

7. suckhoedoisong.vn Cập nhật tình hình dịch bệnh viêm đường hô hấp do Covid-19 tính đến 9h ngày 24/7/2020 (Update on the Pandemic Situation Caused by Covid-19 by 9:00 am. on 24/7/2020). Available online: http:/ / soyte.namdinh.gov.vn/home/tin-tuc/ cap-nhat-tinh-hinh-dich-benh-viem-duong-ho-hap-do-covid-19-tinh-den-9h-ngay-2472020-2130 (accessed on 27 August 2020).

8. Liên, B. 99 ngày Việt Nam không có ca lây nhiễm trong cộng đồng (99 Days in Vietnam There Was No New Case of Infection in the Community). Available online: http:/ / dangcongsan.vn/khoa-giao/99-ngay-viet-nam-khong-co-ca-lay-nhiem-trong-congdong-559938.html (accessed on 7 August 2020).

9. vsh.org.vn COVID-19: Những số liệu cập nhật tình hình mới nhất (COVID-19: The Latest Status Update Data). Available online: http://vsh.org.vn/covid-19-nhung-so-lieu-cap-nhat-tinh-hinh-moi-nhat.htm (accessed on 2 September 2020).

10. Linh, V.; Hiệu, D.; Danh, Q.; Ngôn, P.; Kiện, Y. Toàn cảnh 100 ngày chống dịch Covid-19 tại Việt Nam (Overview of the 100-Day Anti-Epidemic Covid-19 in Vietnam). Available online: https:/ / zingnews.vn/toan-canh-100-ngay-chong-dich-covid-19-tai-vietnam-post1078592.html (accessed on 24 June 2020).

11. HT Ca 416 chấm dứt chuỗi 100 ngày không lây nhiễm Covid-19 trong cộng đồng tại Việt Nam (Case 416 Terminates the 100-Day Series of Covid-19 Non-Infectiousness in the Community in Vietnam). Available online: https://doanhnhansaigon.vn/thoisu-trong-nuoc/ca-416-cham-dut-chuoi-100-ngay-khong-lay-nhiem-covid-19-trong-cong-dong-tai-viet-nam-1099805.html (accessed on 7 August 2020).

12. Worldometers. Info Coronavirus Status Updated in Vietnam. Available online: https://www.worldometers.info/coronavirus/ country/viet-nam/ (accessed on 27 August 2020).

13. MOH Thông báo về ca bệnh 416 tính đến 11h ngày 25 tháng 7 năm 2020 (Notice of Case \#416 to 11 a.m. 25 July 2020 ). Available online: https://ncov.moh.gov.vn/web/guest/dong-thoi-gian?p_p_id=101_INSTANCE_iEPhEhL1XSde\&p_p_lifecycle=0\& p_p_state=normal\&p_p_mode=view\&p_p_col_id=_118_INSTANCE_IrnCPpeHzQ4m_column-1\&p_p_col_count=1\&_101 _INSTANCE_iEPhEhL1XSde_delta=30\&_101_INSTANCE_iEPhEhL1XSde (accessed on 27 August 2020).

14. Medlatec.vn Cảnh báo tốc độ lây lan nhanh chóng của COVID 19 chủng mới xuất hiện tại Đà Nẵng. Available online: https: / / medlatec.vn/tin-tuc/canh-bao-toc-do-lay-lan-nhanh-chong-cua-covid-19-chung-moi-xuat-hien-tai-da-nang-s194-n19064 (accessed on 27 August 2020).

15. Việt, T. Đà Nẵng: Không để COVID-19 lây diện rộng, hạn chế ca tử vong (Da Nang: Do not Let COVID-19 Spread to a Large Extent, Limit Mortality). Available online: https:/ / plo.vn/dich-covid-19/da-nang-khong-de-covid19-lay-dien-rong-han-che-catu-vong-928230.html (accessed on 9 August 2020).

16. Bùi, T. Virus corona: Ý kiến nói đưa người TQ nhập cảnh trái phép vào VN “là tội ác" (Virus Corona: The Idea that Bringing Chinese People Illegally into Vietnam is 'a Crime'). Available online: https:/ / www.bbc.com/vietnamese/vietnam-53563226 (accessed on 9 August 2020).

17. MOH Dòng thời gian (Timeline). Available online: https:/ / ncov.moh.gov.vn/dong-thoi-gian (accessed on 9 August 2020).

18. Khang, M. Đã truy được nguồn gốc dịch Covid-19 bùng phát ở Đà Nẵng (The Origin of the Covid-19 Outbreak in Da Nang Has Been Traced). Available online: http:/ / www.medinet.hochiminhcity.gov.vn/chuyen-muc/da-truy-duoc-nguon-goc-dich-covid19-bung-phat-o-da-nang-c1780-31375.aspx (accessed on 9 August 2020).

19. dw.com How Vietnam Is Winning Its "War" on Coronavirus. Available online: https://www.dw.com/en/how-vietnam-iswinning-its-war-on-coronavirus / a-52929967 (accessed on 7 September 2020).

20. Fages, V.M. Here Are 4 Ways Viet Nam has Managed to Control COVID-19. Available online: https://www.weforum.org/ agenda/2020/05/vietnam-control-covid-19/ (accessed on 3 June 2020).

21. chinhphu.vn Một số thông tin về địa lý Việt Nam (Some Information about Vietnamese Geography). Available online: http: / / www.chinhphu.vn/cttdtcp/vi/nuocchxhcnvn/thongtintonghop/thongtintonghop_dialy.html (accessed on 14 August 2020).

22. danso.org Dân số Việt Nam (Vietnam's Population). Available online: https:/ / danso.org/viet-nam/ (accessed on 8 August 2020).

23. Jones, A. Coronavirus: How “Overreaction” Made Vietnam a Virus Success. Available online: https://www.bbc.com/news/ world-asia-52628283 (accessed on 12 June 2020).

24. Le, S.M. Containing the Coronavirus (COVID-19): Lessons from Vietnam. Available online: https://blogs.worldbank.org/health/ containing-coronavirus-covid-19-lessons-vietnam (accessed on 7 September 2020). 
25. Black, G. Vietnam May Have the Most Effective Response to Covid-19. Available online: https://www.thenation.com/article/ world/coronavirus-vietnam-quarantine-mobilization/ (accessed on 3 June 2020).

26. La, V.P.; Pham, T.H.; Ho, M.T.; Nguyen, M.H.; Nguyen, K.L.P.; Vuong, T.T.; Nguyen, H.K.T.; Tran, T.; Khuc, Q.; Ho, M.T.; et al. Policy response, social media and science journalism for the sustainability of the public health system amid the COVID-19 outbreak: The vietnam lessons. Sustainability 2020, 12, 2931. [CrossRef]

27. Lê, V.L.H.; Nguyễn, T.P. Chính phủ và những chính sách quyết đoán chống đại dịch Covid-19 (Government and Assertive Anti-Pandemic Policies Covid-19). Available online: https:/ /vietnamnet.vn/vn/tuanvietnam/tieudiem/chinh-phu-va-nhungchinh-sach-quyet-doan-chong-dich-covid-19-630565.html (accessed on 28 August 2020).

28. Lê, T. Cấp xã được ban hành văn bản quy phạm pháp luật (Legal Documents Are Issued at the Commune Level). Available online: https:/ / nhandan.com.vn/tin-tuc-su-kien/cap-xa-duoc-ban-hanh-van-ban-quy-pham-phap-luat-235657 (accessed on 28 August 2020).

29. MOH Thông báo số 128/TB-BYT ngày 3 tháng 2 năm 2020 về trường hợp mắc bệnh viêm đường hô hấp cấp do chủng mới của vi rút corona (nCoV) tại tỉnh Vĩnh Phúc. Available online: https://moh.gov.vn/web/dich-benh/van-ban-chi-dao-dieu-hanh/-/ asset_publisher/F4EbfqhQQIIG/content/thong-bao-so-128-tb-byt-ngay-03-02-2020-ve-truong-hop-mac-benh-viem-uongho-hap-cap-do-chung-moi-cua-vi-rut-corona-ncov-tai-tinh-vinh-phuc?inheritRedirect=fa (accessed on 27 August 2020).

30. MOH Thông báo số 134/TB-BYT ngày 3 tháng 2 năm 2020 về trường hợp mắc bệnh viêm đường hô hấp cấp do chủng mới của vi rút corona (nCoV) tại tỉnh Vĩnh Phúc. Available online: https://moh.gov.vn/web/dich-benh/van-ban-chi-dao-dieu-hanh/- / asset_publisher/F4EbfqhQQIIG/content/hong-bao-so-134-tb-byt-ngay-03-02-2020-ve-truong-hop-mac-benh-viem-uong-hohap-cap-do-chung-moi-cua-vi-rut-corona-ncov-tai-tinh-vinh-phuc?inheritRedirect=fal (accessed on 27 August 2020).

31. vietnamtimes.org.vn Prevention of Covid 19: Vietnamese Customs Continues Giving Directives about Exporting Face Masks. Available online: https:/ / vietnamtimes.org.vn/prevention-of-covid-19-vietnamese-customs-continues-giving-directives-aboutexporting-face-masks-18450.html (accessed on 28 August 2020).

32. Hahn, R. COVID-19, F0 to F5, Centralized Quarantine and Cohort Quarantine Guide A to Z in Vietnam. Available online: https:/ / medium.com/@rachelhahn/covid-19-from-f0-to-f5-government-centralized-quarantine-and-cohort-quarantineguide-a-to-z-in-2fc08d0a3f7a (accessed on 28 August 2020).

33. MOH Thông báo về ca bệnh 413 ngày 24/7/2020 (Announcement of Case Confirmed Number 414 on 24/7/2020). Available online: https://ncov.moh.gov.vn/web/guest/dong-thoi-gian?p_p_id=101_INSTANCE_iEPhEhL1XSde\&p_p_lifecycle=0\& p_p_state=normal\&p_p_mode=view\&p_p_col_id=_118_INSTANCE_IrnCPpeHzQ4m_column-1\&p_p_col_count=1\&_101 _INSTANCE_iEPhEhL1XSde_delta=30\&_101_INSTANCE_iEPhEhL1XSde (accessed on 27 August 2020).

34. TTO 2 ca nhiễm virút corona đầu tiên ở Việt Nam tại Bệnh viện Chợ Rẫy là người Trung Quốc (The First Two Cases of Corona Virus Infection in Vietnam at Cho Ray Hospital are Chinese). Available online: https://tuoitre.vn/2-ca-nhiem-virut-corona-dautien-o-viet-nam-tai-benh-vien-cho-ray-la-nguoi-trung-quoc-2020012320171534.htm (accessed on 22 June 2020).

35. Mai, P. "Bệnh nhân lây cho 6 người ở Vĩnh Phúc có thể nồng độ virus cao" ('Patients who Infected 6 People in Vinh Phuc Can Have High Levels of the Virus'). Available online: https:// zingnews.vn/benh-nhan-lay-cho-6-nguoi-o-vinh-phuc-co-the-nongdo-virus-cao-post1047173.html (accessed on 10 September 2020).

36. Hải, H.; Vũ, T. 3 bệnh nhân đầu tiên tại "ổ dịch" Vĩnh Phúc khoẻ khoắn ngày xuất viện (The First 3 Patients at Vinh Phuc "Outbreak" Were Healthy on the Day of Discharge). Available online: https:/ / dantri.com.vn/suc-khoe/3-benh-nhan-dau-tientai-o-dich-vinh-phuc-khoe-khoan-ngay-xuat-vien-20200210144749801.htm (accessed on 29 June 2020).

37. Vietnamplus.vn "Cuộc chiến" chống dịch COVID-19 tại Việt Nam: 100 ngày nhìn lại (“War" Against COVID-19 in Vietnam: 100 Days Look Back). Available online: http:/ / bachmai.gov.vn/tin-tuc-va-su-kien/tin-trong-nganh-menuleft-34/6232-cuocchien-chong-dich-covid-19-tai-viet-nam-100-ngay-nhin-lai.html (accessed on 2 August 2020).

38. customsnews.vn Vietnam Officially Enters 2nd Phase of COVID-19 Fight: Deputy PM. Available online: https:/ / customsnews. vn/vietnam-officially-enters-2nd-phase-of-covid-19-fight-deputy-pm-13752.html (accessed on 3 August 2020).

39. Phatgiao.org.vn Hình ảnh Buddha bar ngày bị phong tỏa (Image of Buddha Bar Day was Blocked). Available online: https: / / phatgiao.org.vn/hinh-anh-buddha-bar-ngay-bi-phong-toa-d40754.html (accessed on 3 September 2020).

40. Trần, T. Dỡ bỏ phong tỏa khu dân cư nơi bệnh nhân 133 sinh sống (Unload Blockade of the Residential Area where Patient 133 Living). Available online: https:/ / nhandan.com.vn/tin-tuc-xa-hoi/do-bo-phong-toa-khu-dan-cu-noi-benh-nhan-133-sinhsong-454377/ (accessed on 6 August 2020).

41. kenh14.vn Trường hợp được cho là $\mathrm{F} 4$ đầu tiên ở Việt Nam mắc Covid-19 như thế nào? (How Was the First Case of F4 in Vietnam Infected with Covid-19?). Available online: https://kenh14.vn/truong-hop-duoc-cho-la-f4-dau-tien-o-viet-nam-mac-covid-19 -nhu-the-nao-20200404120524002.chn (accessed on 6 August 2020).

42. Kiệt, T. Bệnh nhân 91 và quá trình bar Buddha thành nơi lây nhiễm lớn nhất Sài Gòn (Patient 91 and the Buddha Bar Process become the Biggest Infectious Place in Saigon). Available online: https:/ /vietnamnet.vn/vn/thoi-su/benh-nhan-91-va-quatrinh-bar-buddha-thanh-noi-lay-nhiem-covid-19-lon-nhat-sai-gon-627882.html (accessed on 6 August 2020).

43. Lê, L. Đồng Nai tăng cường công tác dập dịch sau ca nhiễm Covid-19 thứ 124 (Dong Nai Strengthens the Work of Quarantine after the 124th Covid-19 Case). Available online: https:/ / thanhnien.vn/thoi-su/dong-nai-tang-cuong-cong-tac-dap-dich-sauca-nhiem-covid-19-thu-124-1200923.html (accessed on 6 August 2020). 
44. Anh, L. Bộ Y tế thông báo khẩn tìm người tiếp xúc với bệnh nhân COVID-19 số 243 (Ministry of Health Informed Urgently to Find Contact Person with COVID-19 Patient Number 243). Available online: https:/ tuoitre.vn/bo-y-te-thong-bao-khan-timnguoi-tiep-xuc-voi-benh-nhan-covid-19-so-243-20200407174248452.htm (accessed on 10 September 2020).

45. Vu, M.; Tran, B.T. The Secret to Vietnam's COVID-19 Response Success A Review of Vietnam's Response to COVID-19 and Its Implications. Available online: https://thediplomat.com/2020/04/the-secret-to-vietnams-covid-19-response-success/ (accessed on 22 August 2020).

46. Bình, T. Thủ tướng: Dịch COVID-19 cơ bản được đẩy lùi, phải sớm phục hồi, phát triển hoạt động kinh tế-xã hội (Prime Minister: The COVID-19 Pandemic has Basically Been Repelled, must soon Recover and Develop Socio-Economic Activities). Available online: https: / / ncov.moh.gov.vn/web/guest/- / thu-tuong-dich-covid-19-co-ban-uoc-ay-lui-phai-som-phuc-hoi-phat-trienhoat-ong-kinh-te-xa-hoi (accessed on 7 August 2020).

47. Chinhphu.vn Thủ tướng: Chuyển sang giai đoạn chống dịch dài hơi hơn, cùng với phát triển KTXH (Prime Minister: Moving to a Longer Anti-Pandemic Phase, along with Socio-Economic Development). Available online: https: //moh.gov.vn/hoat-dong-cua-lanh-dao-bo/-/asset_publisher/TW6LTp1ZtwaN/content/thu-tuong-chuyen-sang-giaioan-chong-dich-dai-hoi-hon-cung-voi-phat-trien-ktxh (accessed on 7 August 2020).

48. Bremmer, I. The Best Global Responses to COVID-19 Pandemic. Available online: https://time.com/5851633/best-globalresponses-covid-19/ (accessed on 26 July 2020).

49. Lai, K.K.R.; Collins, K. Which Country Has Flattened the Curve for the Coronavirus? Available online: https:/ / www.nytimes. com/interactive/2020/03/19/world/coronavirus-flatten-the-curve-countries.html (accessed on 26 July 2020).

50. Rocha, R. What Countries did Right and Wrong in Responding to the Pandemic. Available online: https://www.cbc.ca/news / canada/covid-19-coronavirus-pandemic-countries-response-1.5617898 (accessed on 24 August 2020).

51. Worldometers.info COVID-19 Coronavirus Pandemic. Available online: https://www.worldometers.info/coronavirus/ \#countries (accessed on 25 July 2020).

52. Statista.com COVID-19 Confirmed Case, Death and Recovery Trend in Taiwan 2020. Available online: https://www.statista. com/statistics/1108537/taiwan-novel-coronavirus-covid19-confirmed-death-recovered-trend/ (accessed on 14 August 2020).

53. Gibney, E. Whose coronavirus strategy worked best? Scientists hunt most effective policies. Nature 2020, 581, 15-16. [CrossRef] [PubMed]

54. Minh, H. Đề xuất phương án phòng dịch viêm phổi cấp từ Trung Quốc (Plans to Prevent a New Pneumonia from China) (Published on 9 January 2020). Available online: http:/ / baochinhphu.vn/Suc-khoe/De-xuat-phuong-an-phong-dich-viemphoicap-tu-Trung-Quoc/384647.vgp (accessed on 30 May 2020).

55. PHOEC Có 2 trường hợp mắc viêm phổi cấp ở Trung Quốc đã hồi phục hoàn toàn (2 Cases of Pneumina in China Fully Recovered) (Published on 9 January 2020). Available online: https:/ / suckhoedoisong.vn/da-co-2-truong-hop-bi-viem-phoi-cap-o-trungquoc-hoi-phuc-hoan-toan-n167676.html (accessed on 30 May 2020).

56. Ngọc, D. Deputy PM Orders Ministries to Prevent Acute Pneumonia Spread into Việt Nam. Available online: https: / / vietnamnews.vn/society/571291/deputy-pm-orders-ministries-to-prevent-acute-pneumonia-spread-into-viet-nam.html (accessed on 22 June 2020).

57. MOH Quyết định số 5894 ngày 19 tháng 12 năm 2019 của Bộ y tế về việc ban hành "hướng dẫn thiết lập và vận hành đội đáp ứng nhanh" (Decision No. 5894 Dated 19 December 2019 of the Ministry of Health on Promulgating “Guidelines for the Establishment and Operat. Available online: https:/ / thuvienphapluat.vn/van-ban/the-thao-y-te/Quyet-dinh-5894-QD-BYT-2019-Huongdan-thiet-lap-va-van-hanh-doi-dap-ung-nhanh-431625.aspx (accessed on 12 July 2020).

58. Ly, K. Chỉ đạo thực hiện Công văn số 441/VPCP-KGVX của Văn phòng Chính phủ về việc dịch bệnh viêm phổi tại Trung Quốc (Direct the Implementation of Dispatch No. 441/VPCP-KGVX of the Government Office on the Pneumonia Epidemic in China). Available online: https:/ /vanphong.langson.gov.vn/index.php/en/node/59469 (accessed on 10 September 2020).

59. Vncdc.gov.vn Hai trường hợp bước đầu được xác định nhiễm chủng vi rút Corona mới nCoV tại Việt Nam (Ngày 24 tháng 01 năm 2020) (Two Initial Cases were Infected with a New Corona nCoV Strain in Vietnam (24 January 2020). Available online: http:/ / vncdc.gov.vn/vi/tin-tuc-su-kien/8576/hai-truong-hop-buoc-dau-duoc-xac-dinh-nhiem-chung-vi-rut-coronamoi-ncov-tai-viet-nam-ngay-24-thang-01-nam-2020 (accessed on 10 September 2020).

60. Đặng, L. Nâng mức đáp ứng cao nhất hoạt động Trung tâm đáp ứng khẩn cấp sự kiện y tế công cộng (Raising the Highest Level of Response to the Public Health Event of Urgent Response Center). Available online: https://nhandan.com.vn/tintuc-y-te/nang-muc-dap-ung-cao-nhat-hoat-dong-trung-tam-dap-ung-khan-cap-su-kien-y-te-cong-cong-448014/ (accessed on 10 September 2020).

61. Thu, T. Xuyên tết chống dịch (Through Tet Holiday to Fight the Epidemic). Available online: https://suckhoedoisong.vn/xuyentet-chong-dich-n168212.html (accessed on 10 September 2020).

62. Trang, H.; Ngọc, M. Thương mại lao đao và những nỗ lực của Việt Nam trong chống "giặc" nCoV (Vietnam's hard Trade and Efforts to Fight the "Enemy" of Vietnam). Available online: https://baophapluat.vn/kinh-te/thuong-mai-lao-dao-va-nhung-noluc-cua-viet-nam-trong-chong-giac-ncov-492922.html (accessed on 10 September 2020).

63. MOH Quyết định số 125/QĐ-BYT về việc ban hành hướng dẫn chẩn đoán và điều trị bệnh viêm phổi cấp do chủng vi rút Corona mới (nCoV) (Decision No. 125/QD-BYT on Issuing Guidelines for Diagnosis and Treatment of Acute Pneumonia Caused by New Strain of Corona v. Available online: https:/ / thuvienphapluat.vn/van-ban/The-thao-Y-te/Quyet-dinh-125-QD-BYT-2020-Chandoan-va-dieu-tri-benh-viem-phoi-cap-do-chung-vi-rut-Corona-moi-433264.aspx (accessed on 14 July 2020). 
64. MOH Các văn bản về công tác chẩn đoán điều trị, kiểm soát nhiễm khuẩn bệnh viêm phổi cấp do chủng vi rút Corona mới $(\mathrm{nCoV})$ (Documents about Diagnosis, Treatment and Infection Control of Acute Pneumonia Caused by New Strain of Corona Virus (nCoV)). Available online: https:/ / kcb.vn/cac-van-ban-ve-cong-tac-chan-doan-dieu-tri-kiem-soat-nhiem-khuan-benhviem-phoi-cap-do-chung-vi-rut-corona-moi-ncov.html (accessed on 14 July 2020).

65. Vietnamplus.vn Bộ Y tế ra công văn khẩn về phòng, chống bệnh viêm phổi cấp (The Ministry of Health Issues an Emergency Dispatch on Prevention and Control of Acute Pneumonia). Available online: http://trungtamytemongcai.vn/index.php?option= com_content\&view=article\&id=1160\%3Ab-y-t-ra-cong-vn-khn-v-phong-chng-bnh-viem-phi-cp\&catid=109\%3Athong-tin-yte\&Itemid=1https: / / thuvienphapluat.vn/cong-van/the-thao-y-te/Cong-van-62-KCB-NV-2020-phat-hien-som-v (accessed on 14 July 2020).

66. MOH Quyết định số $137 /$ QĐ-BYT của Bộ Y tế ngày 17 tháng 1 năm 2020 ban hành kế hoạch phòng chống dịch bệnh truyền nhiễm năm 2020 (Decision No. 137/QD-BYT of the Ministry of Health, 17 January 2020 on Promulgating the Plan for Prevention and Control of Infec. Available online: https:/ / thuvienphapluat.vn/van-ban/The-thao-Y-te/Quyet-dinh-137-QD-BYT-2020-Kehoach-Phong-chong-dich-benh-truyen-nhiem-433228.aspx (accessed on 14 July 2020).

67. MOH Công văn khẩn số 62/KCB-NV ngày 17 tháng 1 năm 2020 của Bộ Y tế về việc phát hiện sớm và chuẩn bị tốt việc phòng, chống bệnh dịch viêm phổi cấp do Corona virut mới (Emergency Dispatch No. 62/KCB-NV Dated 17 January 2020 of the Ministry of Health on Ear. Available online: https: / thuvienphapluat.vn/cong-van/The-thao-Y-te/Cong-van-62-KCB-NV-2020 -phat-hien-som-va-chuan-bi-tot-viec-phong-chong-benh-dich-viem-phoi-cap-433524.aspx (accessed on 14 July 2020).

68. cungphuot.info Các cửa khẩu giữa Việt Nam Trung Quốc (The Border Gates between Vietnam and China). Available online: https: / / cungphuot.info/cac-cua-khau-giua-viet-nam-trung-quoc-post4916.cp (accessed on 13 July 2020).

69. MOH Quyết định 156/QĐ-BYT ngày 20 tháng 1 năm 2020 về việc ban hành kế hoạch đáp ứng với bệnh viêm phổi cấp do chủng mới của vi rút Corona (Decision Deci 156/QD-BYT dated 20 January 2020 on the Promulgation of a Plan to Respond to Acute Pneumonia Cause. Available online: https:/ / thuvienphapluat.vn/van-ban/The-thao-Y-te/Quyet-dinh-156-QD-BYT-2020-Kehoach-dap-ung-voi-benh-viem-phoi-cap-do-chung-vi-rut-Corona-433464.aspx (accessed on 14 July 2020).

70. MOH Quyết định 181/QĐ-BYT ngày 20 tháng 1 năm 2020 quyết định về việc ban hành hướng dẫn tạm thời giám sát và phòng chống bệnh viêm đường hô hấp cấp do chủng mới của vi rút Corona (nCoV) (Decision 181/QD-BYT dated 20 January 2020 Regarding the Issuance of te. Available online: https: / / thuvienphapluat.vn/van-ban/The-thao-Y-te/Quyet-dinh-181-QD-BYT2020-Huong-dan-phong-chong-benh-viem-duong-ho-hap-cap-do-Corona-433299.aspx (accessed on 14 July 2020).

71. VNA MoH Issues Urgent Instructions Over Chinese Disease Outbreak. Available online: https:/ / en.vietnamplus.vn/moh-issuesurgent-instructions-over-chinese-disease-outbreak/167679.vnp (accessed on 22 June 2020).

72. MOH Chỉ thị 03/CT-BYT ngày 22 tháng 1 năm 2020 về việc tăng cường công tác phòng, chống dịch bệnh viêm đường hô hấp cấp do chủng mới của vi rút corona (Directive 03/CT-BYT Dated 22 January 2020 on Strengthening the Prevention and Control of Acute Respiratory. Available online: https:/ / thuvienphapluat.vn/van-ban/The-thao-Y-te/Chi-thi-03-CT-BYT-2020-tang-cuongcong-tac-phong-chong-dich-benh-viem-duong-ho-hap-cap-Corona-433305.aspx (accessed on 14 July 2020).

73. Vi.wikipedia.org Nhà nước Cộng hòa xã hội chủ nghĩa Việt Nam (State of the Socialist Republic of Vietnam). Available online: https://vi.wikipedia.org/wiki/Nhà_nước_Cộng_hòa_xã_hội_chủ_nghĩa_Việt_Nam (accessed on 29 August 2020).

74. Vi.wikipedia.org Thành phố Hồ Chí Minh (Ho Chi Minh City). Available online: https://vi.wikipedia.org/wiki/Thành_phố_Hồ_ Chí_Minh (accessed on 29 August 2020).

75. Vi.wikipedia.org Thành phố trực thuộc trung ương (Việt Nam) (Cities under Central Authority (Vietnam)). Available online: https://vi.wikipedia.org/wiki/Thành_phố_trực_thuộc_trung_ương_(Việt_Nam) (accessed on 29 August 2020).

76. Chinhphu.vn "Chiến lược" phòng chống COVID-19 thời gian tới trước sức ép lớn ("Strategy" of COVID-19 Prevention in the Coming Time under Great Pressure). Available online: https://moh.gov.vn/tin-noi-bat/-/asset_publisher/3Yst7YhbkA5j/ content/-chien-luoc-phong-chong-covid-19-thoi-gian-toi-truoc-suc-ep-lon (accessed on 27 July 2020).

77. Watson, W. This Index Helps Compare Countries' Differing COVID-19 Policies. Available online: https://theprovince.com/ opinion/this-index-helps-compare-countries-differing-covid-19-policies/wcm/c904f730-98ec-4ba3-a6fa-edef617a7c49 (accessed on 14 July 2020).

78. EGH Emerging COVID-19 Success Story: Vietnam's Commitment to Containment. Available online: https:/ / ourworldindata. org/covid-exemplar-vietnam (accessed on 31 July 2020).

79. Reguly, E. With Zero Pandemic Deaths, Vietnam sets the Standard for COVID-19 Fight. Available online: https: //www.theglobeandmail.com/world/article-with-zero-pandemic-deaths-vietnam-sets-the-standard-for-covid- $1 /$ ?fbclid= IwAR3IMET9mhDF2dWWn6nyqA75OTXVIbos8dOjkZvlE3N-iTbygrzXtG1ZQms (accessed on 10 September 2020).

80. To, H.T. How Vietnam Is Winning Its War Against COVID-19. Available online: https://www.asiapacific.ca/publication/howvietnam-winning-its-war-against-covid-19 (accessed on 12 June 2020).

81. Chinhphu.vn Chúng ta đã triển khai một loạt biện pháp chưa từng có (We Have Implemented an Unprecedented Series of Measures). Available online: https://moh.gov.vn/hoat-dong-cua-lanh-dao-bo/-/asset_publisher/TW6LTp1ZtwaN/content/ chung-ta-a-trien-khai-mot-loat-bien-phap-chua-tung-co (accessed on 10 September 2020).

82. Vũ, L. Chặn dịch Covid-19 và những chính sách chưa từng có tiền lệ (Block Covid-19 and Unprecedented Policies). Available online: https://luatvietnam.vn/tin-phap-luat/chan-dich-covid-19-va-nhung-chinh-sach-chua-tung-co-tien-le-230-24594article.html (accessed on 29 July 2020). 
83. MOH Công văn số 1119/BYT-DP ngày 6/3/2020 về việc thực hiện áp dụng khai báo y tế đối với COVID-19 (Dispatch No. 1119/BYT-DP 6 March 2020 on the Application of Medical Declarations to COVID-19). Available online: https: / / thuvienphapluat.vn/cong-van/The-thao-Y-te/Cong-van-1119-BYT-DP-2020-thuc-hien-ap-dung-khai-bao-y-te-doivoi-COVID-19-436636.aspx (accessed on 3 August 2020).

84. Đô, B.; Thanh, L. Nội Bài siết kiểm tra nhập cảnh (Noi Bai Tightened Entry Check). Available online: https://vnexpress.net/noibai-siet-kiem-tra-nhap-canh-4068388.html (accessed on 31 August 2020).

85. NSCPC Công văn số 1436/CV-BCĐ ngày 20/3/2020 về việc triển khai ứng dụng khai báo y tế toàn dân NCOVI (Dispatch No 1436/CV-BCĐ Dated on 20 March 2020 on the Application of NCOVI's Universal Health Declaration Application). Available online: https: / / thuvienphapluat.vn/ cong-van/The-thao-Y-te/Cong-van-1436-CV-BCD-2020-trien-khai-ung-dung-khai-baoy-te-toan-dan-NCOVI-437702.aspx (accessed on 3 August 2020).

86. Hà, M. Bắt đầu khai báo y tế tự nguyện (Starting Voluntary Health Declarations). Available online: https://thanhnien.vn/thoisu/bat-dau-khai-bao-y-te-tu-nguyen-1193477.html (accessed on 31 August 2020).

87. Trần, H. Bộ GD-ĐT yêu cầu 25,5 triệu học sinh, sinh viên, giáo viên khai báo y tế (The Ministry of Education and Training Required 25.5 Million Pupils, Students and Teachers to Make Medical Declarations). Available online: https://tuoitre.vn/bo-gddt-yeu-cau-25-5-trieu-hoc-sinh-sinh-vien-giao-vien-khai-bao-y-te-20200326165845187.htm (accessed on 6 August 2020).

88. Phùng, T. Từ 21-3 đi xe khách, tàu hỏa, máy bay trong nước phải khai báo y tế điện tử (From 21 March Passenger Moving by Domestic Cars, Trains, Aircraft Have to Make Electronic Medical Declaration). Available online: https://tuoitre.vn/tu-21-3-dixe-khach-tau-hoa-may-bay-trong-nuoc-phai-khai-bao-y-te-dien-tu-20200321182910276.htm (accessed on 5 August 2020).

89. Dung, N. Việt Nam là 1 trong 4 quốc gia phân lập thành công Covid-19 (Vietnam is One of the Four Countries that Successfully Isolated Covid-19). Available online: https://nld.com.vn/suc-khoe/viet-nam-la-1-trong-4-quoc-gia-phan-lap-thanh-congcovid-19-20200212213559627.htm (accessed on 3 September 2020).

90. Linh, T. Việt Nam nghiên cứu sự thay đổi của virus SARS-CoV-2 (Vietnam Studying the Changes of SARS-CoV-2 Virus). Available online: https:/ / laodong.vn/xa-hoi/viet-nam-nghien-cuu-su-thay-doi-cua-virus-sars-cov-2-796078.1do (accessed on 5 August 2020).

91. Hằng, T. Việt Nam chế tạo bộ kit phát hiện Sars-Cov-2 công suất 10.000 bộ/ngày (Vietnam Manufactured Sars-Cov-2 Detection Kit with Capacity of 10,000 Sets/Day). Available online: https:/ thanhnien.vn/thoi-su/viet-nam-che-tao-bo-kit-phat-hien-sarscov-2-cong-suat-10000-bongay-1191346.html (accessed on 3 September 2020).

92. P.H 63/63 tỉnh, thành cho học sinh nghỉ học để phòng dịch nCoV (63/63 Provinces and Cities Allow Students to Leave Schools to Prevent Epidemic Diseases). Available online: https:/ / suckhoedoisong.vn/63-63-tinh-thanh-cho-hoc-sinh-nghi-hoc-de-phongdich-ncov-n168605.html (accessed on 31 August 2020).

93. PM Công điện số 156/CĐ-TTg của Thủ tướng Chính phủ: Về việc tăng cường phòng, chống dịch bệnh viêm đường hô hấp cấp do chủng mới của vi rút Corona gây ra (Telegram No. 156/CĐ-TTg on Strengthening Prevention and Control of Acute Respiratory Infection Pandemi). Available online: http://vanban.chinhphu.vn/portal/page/portal/chinhphu/hethongvanban? class_id=2\&mode=detail\&document_id=199003 (accessed on 30 June 2020).

94. suckhoedoisong.vn Các tỉnh đã công bố dịch dừng tất cả lễ hội, quyết định cho học sinh nghỉ học. Available online: https: / / suckhoedoisong.vn/cac-tinh-da-cong-bo-dich-dung-tat-ca-le-hoi-quyet-dinh-cho-hoc-sinh-nghi-hoc-n168412.html (accessed on 31 August 2020).

95. GO Công văn số 716/VPCP-KGVX ngày 02/02/2020 về việc xin ý kiến chỉ đạo cho phép học sinh, sinh viên nghỉ học phòng, chống dịch nCoV. Available online: https://moh.gov.vn/web/dich-benh/cac-van-ban-chi-dao-cua-dang-nha-nuoc/-/asset_ publisher/zRev3D15XCJB/content/cong-van-so-716-vpcp-kgvx-ngay-02-02-2020-ve-viec-xin-y-kien-chi-ao-cho-phep-hocsinh-sinh-vien-nghi-hoc-phong-chong-dich-ncov?inheritRedirect=fa (accessed on 31 August 2020).

96. Nguyễn, T. Phòng Covid-19: Học sinh Hà Nội tiếp tục nghỉ học, TP.HCM trưa nay quyết định (Covid-19 Room: Hanoi Students Continue to Leave School, Ho Chi Minh City this Afternoon will Decide). Available online: https://thanhnien.vn/giao-duc/ phong-covid-19-hoc-sinh-ha-noi-tiep-tuc-nghi-hoc-tphcm-trua-nay-quyet-dinh-1189002.html (accessed on 6 August 2020).

97. Tuoitre.vn Nhiều tỉnh cho học sinh nghỉ tới giữa tháng 4 để tránh COVID-19 (Many Provinces Have Had Students LEAVE School Until Mid-April to Avoid COVID-19). Available online: https:/ / tuoitre.vn/nhieu-tinh-cho-hoc-sinh-nghi-toi-giua-thang-4-detranh-covid-19-20200327103819933.htm (accessed on 6 August 2020).

98. Nguyễn, Q. Dịch COVID-19: 63 tỉnh, thành tiếp tục cho học sinh nghỉ học (COVID-19: 63 Provinces and Cities Continue to Keep Students out of Schools). Available online: https:/ / plo.vn/xa-hoi/giao-duc/dich-covid19-63-tinh-thanh-tiep-tuc-cho-hoc-sinhnghi-hoc-900877.html (accessed on 6 August 2020).

99. Sơn, P. Hà Nội dừng 12.400 chuyến xe buýt (Hanoi Stops 12,400 Bus Trips). Available online: https://vnexpress.net/ha-noidung-12-400-chuyen-xe-buyt-4075619.html (accessed on 6 August 2020).

100. Trang, V. Chính thức: 63 tỉnh thành cho tất cả học sinh nghỉ học, hàng loạt tỉnh chưa có lịch đi học lại (Officially: 63 Provinces/Cities Drop all Pupils, Students, a Series of Provinces Have no Schedule to Return to Schools). Available online: https://kenh14.vn/ chinh-thuc-63-tinh-thanh-cho-tat-ca-hoc-sinh-nghi-hoc-nhieu-tinh-chua-co-lich-di-hoc-lai-20200328120219783.chn (accessed on 2 September 2020).

101. Trang, V. Học sinh, sinh viên trở lại trường sau kỳ nghỉ đại dịch bệnh: "Xa trường lâu quá mình đi lạc giữa các lớp, không nhớ vị trí tòa nhà" (Pupils and Students Returning to School After a Pandemic Vacation: "Long Time away from School, I Have Been Lost between. Available online: https:/ / kenh14.vn/hoc-sinh-sinh-vien-tro-lai-truong-sau-ky-nghi-dich-xa-truong-lau-quaminh-di-lac-giua-cac-lop-khong-nho-vi-tri-toa-nha-2020050409061825.chn (accessed on 8 August 2020). 
102. MOH Công văn 478/QĐ-BCĐQG về việc kiện toàn các đội cơ động phản ứng nhanh chống dịch viêm đường hô hấp cấp do Virut Corona 2019. Available online: https://moh.gov.vn/web/dich-benh/cac-van-ban-chi-dao-cua-ban-chi-dao/-/asset_publisher/ TKPnyGZHotzj/content/cong-van-478-q-bc-qg-ve-viec-kien-toan-cac-oi-co-ong-phan-ung-nhanh-chong-dich-viem-uongho-hap-cap-do-virut-corona-2019?inheritRedirect=false\&redi (accessed on 1 September 2020).

103. who.int Bệnh viện tại Việt Nam (Hospitals in Vietnam). Available online: https://www.who.int/vietnam/vi/healthtopics/hospitals\#: :text=BệnhviệncôngởViệt,ởkhuvựcthànhthị (accessed on 1 September 2020).

104. PM Chỉ thị 06/CT-TTg về việc tăng cường các biện pháp phòng, chống trước các diễn biến phức tạp mới của dịch bệnh viêm đường hô hấp cấp do chủng mới của vi rút Corona gây ra (Directive No. 06/CT-TTg on Strengthening Measures to Prevent and Control Against. Available online: http://vanban.chinhphu.vn/portal/page/portal/chinhphu/hethongvanban?class_id=2\& _page $=1 \&$ mode $=$ detail\&document_id=198974 (accessed on 29 June 2020).

105. Baotintuc.vn Hà Nội họp khẩn về chống dịch Covid-19: Tình hình dịch bệnh vẫn đang nằm trong tầm kiểm soát (Hanoi has an Urgent Meeting on the Fight Against the Covid-19 Epidemic: The Epidemic is Still under Control). Available online: https:/ / baodanang.vn/channel/5399/202003/ha-noi-hop-khan-ve-chong-dich-covid-19-tinh-hinh-dich-benh-van-dangnam-trong-tam-kiem-soat-3273363/ (accessed on 3 September 2020).

106. Phan, H. Thái Nguyên họp khẩn ứng phó với diễn biến mới từ “ổ dịch Bệnh viện Bạch Mai” (Thai Nguyen held an Emergency Meeting to Respond to New Developments from the 'Outbreak of Bach Mai Hospital'). Available online: https://thanhnien.vn/thoisu/thai-nguyen-hop-khan-ung-pho-voi-dien-bien-moi-tu-o-dich-benh-vien-bach-mai-1202835.html (accessed on 28 March 2020).

107. Suckhoedoisong.vn Hà Nội họp khẩn về ca dương tính với COVID-19 (Hanoi Urgent Meeting for COVID-19 Positive Case). Available online: https: / suckhoedoisong.vn/ha-noi-truong-hop-ve-qua-vung-dich-tron-khai-bao-y-te-da-duong-tinh-voicovid-19-n169769.html (accessed on 2 September 2020).

108. Baodautu.vn Hà Nội họp khẩn, quyết định phong tỏa thôn Hạ Lôi do liên quan bệnh nhân 243 (Hanoi Meeting Urgently, Decided to Blockade Ha Loi Village Due to Related Patient 243). Available online: https:/ / baodautu.vn/ha-noi-hop-khan-quyet-dinhphong-toa-thon-ha-loi-do-lien-quan-benh-nhan-243-d119623.html (accessed on 3 September 2020).

109. Phan, T. Bệnh nhân 251 rất phức tạp, Sở Y tế Hà Nam họp khẩn trong đêm (Patient 251 Is Very Complicated, Ha Nam Department of Health Meets Urgently at Night). Available online: https: / / plo.vn/dich-covid-19/benh-nhan-251-rat-phuc-tap-so-y-te-hanam-hop-khan-trong-dem-903890.html (accessed on 3 September 2020).

110. Vương, T. Đồng Nai họp khẩn sau khi ghi nhận ca đầu tiên mắc Covid-19 (Dong Nai Met Urgently after Recording the First Case of Covid-19). Available online: https://nhandan.com.vn/tin-tuc-y-te/dong-nai-hop-khan-sau-khi-ghi-nhan-ca-dau-tien-maccovid-19-454640/ (accessed on 3 September 2020).

111. Kiên, K. Lai Châu họp khẩn, chỉ đạo rà soát số người tiếp xúc với bệnh nhân 133 (Lai Chau Met Urgently, Directing the Review of the Number of People Contacting Patients 133). Available online: http:/ / dienbientv.vn/tin-tuc-su-kien/xa-hoi/202003/lai-chauhop-khan-chi-dao-ra-soat-so-nguoi-tiep-xuc-voi-benh-nhan-133-5674895/ (accessed on 3 September 2020).

112. Ncov.moh.gov.vn Hà Giang họp khẩn, cách ly 2 xã, 2 bệnh viện, phong tỏa 1 thôn liên quan ca bệnh 268 (Ha Giang Had an Emergency Meeting, Quarantined 2 Communes, 2 Hospitals, and Blocked 1 Related Village in CC \#268). Available online: https: //ncov.moh.gov.vn/en/- / ha-giang-hop-khan-cach-ly-2-xa-2-benh-vien-phong-toa-1-thon-lien-quan-ca-benh-268 (accessed on 5 September 2020).

113. VNA Vietnam Declares Novel Coronavirus Epidemic. Available online: https:/ /web.archive.org/web/20200201121402/https: / / en.vietnamplus.vn/vietnam-declares-novel-coronavirus-epidemic/168021.vnp (accessed on 16 July 2020).

114. PM Chỉ thị số 13/CT-TTg ngày 11 tháng 3 năm 2020 về việc tiếp tục đẩy mạnh phòng, chống dịch COVID-19 trong tình hình mới (Directive No. 13/CT-TTg Dated on 11 March 2020 on Continuing to Promote Prevention and Control of COVID-19 in the New Situation). Available online: https:/ / thuvienphapluat.vn/van-ban/The-thao-Y-te/Chi-thi-13-CT-TTg-2020-tiep-tuc-daymanh-phong-chong-dich-COVID-19-trong-tinh-hinh-moi-436876.aspx (accessed on 3 August 2020).

115. Anh, L. Công dân 59 quốc gia đến Việt Nam phải cách ly tập trung 14 ngày (Citizens of 59 Countries Visiting Vietnam Must Be Isolated for 14 Days). Available online: https:/ / tuoitre.vn/cong-dan-59-quoc-gia-den-viet-nam-phai-cach-ly-tap-trung-14 -ngay-20200320125946531.htm (accessed on 3 August 2020).

116. Lê, H. Toàn cảnh các ca nhiễm Covid-19 tại Việt Nam tới ngày 12.3 (Overview of the Confirmed Cases of Covid-19 in Vietnam up to 12 March). Available online: https: / / thanhnien.vn/thoi-su/toan-canh-cac-ca-nhiem-covid-19-tai-viet-nam-toi-ngay-123-11 94645.html (accessed on 1 August 2020).

117. Fleming, S. Viet Nam Shows how You can Contain COVID-19 with Limited Resources. Available online: https:/ /www.weforum. org/agenda/2020/03/vietnam-contain-covid-19-limited-resources/ (accessed on 5 June 2020).

118. SGGP Binh Thuan Locks Down 2 Streets After 5 People Tested Positive for COVID-19. Available online: https:/ /vietnaminsider. vn/binh-thuan-locks-down-2-streets-after-5-people-tested-positive-for-covid-19/ (accessed on 7 September 2020).

119. Nhân, T. Ninh Thuận: Phong tỏa khu dân cư Văn Lâm 3, nơi có bệnh nhân mắc Covid-19 (Ninh Thuan: Blockade of Van Lam 3 Residential Area, Where There Are COVID-19 Patients). Available online: https://thanhnien.vn/thoi-su/ninh-thuan-phong-toakhu-dan-cu-van-lam-3-noi-co-benh-nhan-mac-covid-19-1197445.html (accessed on 6 June 2020).

120. Tuoitrenews.vn COVID-19 Adds to Worry in Vietnam's Drought-Struck Cham Village. Available online: https:/ tuoitrenews. $\mathrm{vn} /$ news/features/20200323/covid19-adds-to-worry-in-vietnams-droughtstruck-cham-village/53629.html (accessed on 5 September 2020). 
121. Tú, N. Bến Tre ghi nhận ca bệnh Covid-19 đầu tiên, là bệnh nhân thứ 123 của cả nước (Ben Tre Recorded the First Case of Covid-19, the 123rd Patient in the Country). Available online: http:/ / kinhtedothi.vn/ben-tre-ghi-nhan-ca-benh-covid-19-dautien-la-benh-nhan-thu-123-cua-ca-nuoc-378634.html (accessed on 7 September 2020).

122. Bình, B. Bến Tre: Căng thẳng cách ly gần 1.600 người ở ấp Thừa Lợi vì Covid-19 (Ben Tre: Tensions Isolated Nearly 1600 People in Thua Loi Hamlet Because of Covid-19). 2020. Available online: https:/ / thanhnien.vn/thoi-su/ben-tre-cang-thang-cach-ly-gan1600-nguoi-o-ap-thua-loi-vi-covid-19-1200569.html (accessed on 7 September 2020).

123. Tuoitrenews.vn Vietnam Hamlet with Nearly 1600 People Isolated after Girl Tests Positive for COVID-19. Available online: https: / tuoitrenews.vn/news/society / 20200323/vietnam-hamlet-with-nearly-1600-people-isolated-after-girl-tests-positivefor-covid19/53641.html (accessed on 7 September 2020).

124. Hà, T. Lai Châu: Cách ly 26 trường hợp tiếp xúc với bệnh nhân 133 dương tính SARS-CoV-2 (Lai Chau: Quarantined 26 Cases of Contact with Case Confirmed Number 133). Available online: https:/ / baotainguyenmoitruong.vn/lai-chau-cach-ly-26-truonghop-tiep-xuc-voi-benh-nhan-133-duong-tinh-sars-cov-2-301864.html (accessed on 6 August 2020).

125. Vietnamplus.vn Hanoi Hastens Efforts to Handle COVID-19 Hotbed at Bach Mai Hospital. Available online: https://en. vietnamplus.vn/hanoi-hastens-efforts-to-handle-covid19-hotbed-at-bach-mai-hospital/170877.vnp (accessed on 5 August 2020).

126. Hà, P. BV Bạch Mai ngưng đón bệnh nhân, cách ly toàn bệnh viện (Bach Mai Hospital Stopped Receiving Patients, Quarantined the Whole Hospital). Available online: https:/ / plo.vn/dich-covid-19/bv-bach-mai-ngung-don-benh-nhan-cach-ly-toan-benhvien-900527.html (accessed on 5 August 2020).

127. Tuoitre.vn Nhắn tin yêu cầu 18.000 người đã khám bệnh ở Bạch Mai thực hiện cách ly (Texting Request 18,000 People Who Have Been Examined in Bach Mai to do Isolation). Available online: https: / tuoitre.vn/nhan-tin-yeu-cau-18-000-nguoi-da-khambenh-o-bach-mai-thuc-hien-cach-ly-20200330153756148.htm (accessed on 5 August 2020).

128. Bình, T. Phong toả toàn bộ Thị trấn Đồng Văn -Hà Giang để phòng chống dịch COVID-19 (Blockade the Whole Town of Dong Van-Ha Giang to Prevent COVID-19 Pandemic). Available online: https://ncov.moh.gov.vn/en/-/phong-toa-toan-bo-thi-tranong-van-ha-giang-e-phong-chong-dich-covid-19 (accessed on 4 September 2020).

129. Onishi T Vietnam Locks Down Son Loi District near Hanoi for 20 Days. Available online: https://asia.nikkei.com/Spotlight/ Coronavirus/Vietnam-locks-down-Son-Loi-district-near-Hanoi-for-20-days (accessed on 28 June 2020).

130. Võ, N. Cô gái nhiễm Covid-19 ở Hà Nội khiến dân mạng lo lắng, lên án việc không tự giác khai báo (The Girl Infected with Covid19 in Hanoi Made Netizens Worry and Condemn Due to Not Voluntarily Reporting). Available online: https://thanhnien.vn/doisong / co-gai-nhiem-covid-19-o-ha-noi-khien-dan-mang-lo-lang-len-an-viec-khong-tu-giac-khai-bao-1192122.html (accessed on 3 August 2020).

131. Tuân, V. Việt Nam "cách ly toàn xã hội” trong 15 ngày (Vietnam Implementing "Social Isolation" for 15 Days). Available online: https: / vnexpress.net/viet-nam-cach-ly-toan-xa-hoi-trong-15-ngay-4077462.html (accessed on 5 August 2020).

132. An, N. Thực hiện cách ly toàn xã hội từ 0h ngày 1-4 (Applying Entire Social Isolation from 0 h on 1-4). Available online: https: / / tuoitre.vn/thuc-hien-cach-ly-toan-xa-hoi-tu-0h-ngay-1-4-20200331115839.htm (accessed on 5 August 2020).

133. Anh, X. Miễn phí điều trị cho những người bị nhiễm Covid-19 (Free Treatment for People Infected with Covid-19). Available online: https://nhandan.com.vn/bhxh-va-cuoc-song/mien-phi-dieu-tri-cho-nhung-nguoi-bi-nhiem-covid-19-451760/ (accessed on 8 August 2020).

134. Bình, Đ. Thủ tướng ban hành quyết định về gói hỗ trợ 62.000 tỉ đồng (The Prime Minister Issued a Decision on the VND 62,000 Billion Support Package). Available online: https: / tuoitre.vn/thu-tuong-ban-hanh-quyet-dinh-ve-goi-ho-tro-62-000-tidong-20200425193449618.htm (accessed on 6 August 2020).

135. Sang, C. Hoàng Tuấn Anh, "cha đẻ” ATM gạo: Ý tưởng hiệu quả và được ủng hộ là điều tuyệt vời nhất (Hoang Tuan Anh, "Father" of rice ATM: Effective and Supported Ideas Are the Best Things). Available online: https://baodautu.vn/hoang-tuananh-cha-de-atm-gao-y-tuong-hieu-qua-va-duoc-ung-ho-la-dieu-tuyet-voi-nhat-d121185.html (accessed on 5 September 2020).

136. Lĩnh, T.; An, Đ. Nhiều cây "ATM gạo" miễn phí xuất hiện ủng hộ người nghèo (Many Free "ATM Rice" Trees Appeared to Support for the Poor). Available online: http:/ / cand.com.vn/nhip-cau-nhan-ai/Ben-Tre-khanh-thanh-may-ATM-gao-mien-phicho-nguoi-ngheo-591575/ (accessed on 5 September 2020).

137. CM Lan tỏa mô hình "ATM gạo" cho người (Spreading the Model of "Rice ATM" to the Poor). Available online: http:// dangcongsan.vn/xa-hoi/lan-toa-mo-hinh-atm-gao-cho-nguoi-ngheo-553120.html (accessed on 5 September 2020).

138. Giang, H.; Yên, N. Cận cảnh siêu thị 0 đồng đầu tiên ở Sài Gòn (Close-up of the First 0 Dong Supermarket in Saigon). Available online: https: / plo.vn/xa-hoi / can-canh-sieu-thi-0-dong-dau-tien-o-sai-gon-907313.html (accessed on 5 September 2020).

139. Tin, T. Nước mắt 0 đồng (Tears VND 0). Available online: https://vietnamnet.vn/vn/doi-song/gia-dinh/nguoi-ngheo-batkhoc-o-sieu-thi-0-dong-sai-gon-635624.html (accessed on 8 August 2020).

140. Thảo, T. Siêu thị 0 đồng cho người nghèo giữa mùa dịch (Supermarket 0 VND for the Poor in the Middle of the Pandemic Season). Available online: https:/ / www.danang.gov.vn/web/guest/viruscorona/ chi-tiet?id=39294\&_c=100000150 (accessed on 5 September 2020).

141. vi.wikipedia.org Đại dịch COVID-19 tại Việt Nam (COVID-19 Pandemic in Vietnam). Available online: https://vi.wikipedia.org/ wiki/Đại_dịch_COVID-19_tại_Việt_Nam (accessed on 24 July 2020).

142. Vietnamnews.vn US Grants Việt Nam US\$9.5 Million to Combat COVID-19. Available online: https://vietnamnews.vn/politicslaws/716093/us-grants-viet-nam-us95-million-to-combat-covid-19.html (accessed on 12 October 2020). 
143. Phan, D. Vietnam's ‘Coronavirus Song' Goes Viral Again with American Cover Version. Available online: https:/ /e.vnexpress. net/news/life/culture/vietnam-s-coronavirus-song-goes-viral-again-with-american-cover-version-4069458.html (accessed on 19 August 2020).

144. En.nhandan.org.vn Official English Version of “Ghen Co Vy" Released. Available online: https:/ / en.nhandan.org.vn/culture/ item/8563802-official-english-version-of- $\backslash \mathrm{T} 1 \backslash$ textquotedblleftghen-co-vy $\backslash \mathrm{T} 1 \backslash$ textquotedblright-released.html (accessed on 19 August 2020).

145. vov.vn "Ghen cô Vy" gây bão quốc tế với nhiều phiên bản chuyển ngữ ("Jealous Coronavirus" Caused an International Storm with Many Translated Versions). Available online: http:/ /baoquangninh.com.vn/van-hoa/202003/ghen-co-vy-gay-bao-quoc-tevoi-nhieu-phien-ban-chuyen-ngu-2476220/index.htm (accessed on 4 September 2020).

146. Theculturetrip.com The Covid-19-Inspired Songs Popping Up Around the World. Available online: https://theculturetrip.com/ asia/vietnam/articles/covid-19-songs-go-viral-to-educate-people-to-fight-the-outbreak/ (accessed on 25 September 2020).

147. Nguyễn, L. Cô giáo làm 'dậy sóng' cộng đồng mạng với bài thơ đặc biệt về dịch Covid-19 (The Teacher Rocked the Online Community with a Special Poem about the Covid-19 Pandemic). Available online: https://thanhnien.vn/giao-duc/co-giao-lamday-song-cong-dong-mang-voi-bai-tho-dac-biet-ve-dich-covid-19-1184146.html (accessed on 2 June 2020).

148. Cuocsongantoan.vn Kết quả ngày 31/3 của "Thi thơ vui chiến Cô Vy" (The Result of March 31st of "Poetry Contest of the War of Co Vy"). Available online: https:/ / cuocsongantoan.vn/ ket-qua-ngay-313-cua-thi-tho-vui-chien-co-vy-41336.html (accessed on 15 December 2020).

149. Tuyết, N. Thơ cho người ở tuyến đầu chống dịch (Poetry for Anti-Epidemic Frontline People). Available online: https://www. hcmcpv.org.vn/tin-tuc/tho-cho-nguoi-o-tuyen-dau-chong-dich-1491863653 (accessed on 15 December 2020).

150. Sương, N. Lịch phát sóng, nội dung phim "Những ngày không quên” trên VTV1 (Broadcast Schedule, Content of the Movie "Unforgettable Days" on VTV1). Available online: https:/ / thoidai.com.vn/lich-phat-song-noi-dung-phim-nhung-ngay-khong-quentren-vtv1-104456.html\#: :text=Lịchphátsóngphim“Nhữngngàykhôngquên” \&text=Lịchphátsóngphimvào,Đừngbắtemphảiquên”. (accessed on 24 August 2020).

151. BTV Lịch phát sóng phim Những ngày không quên trên VTV1 (The Film Schedule of The Unforgettable Days on VTV1). Available online: https: / tintucvietnam.vn/lich-phat-song-phim-nhung-ngay-khong-quen-tren-vtv1-d235401.html (accessed on 2 June 2020).

152. Erkhembayar, R.; Dickinson, E.; Badarch, D.; Narula, I.; Warburton, D.; Thomas, G.N.; Ochir, C.; Manaseki-Holland, S. Early policy actions and emergency response to the COVID-19 pandemic in Mongolia: Experiences and challenges. Lancet Glob. Health 2020, 8, e1234-e1241. [CrossRef]

153. Schnirring, L. Japan has 1st Novel Coronavirus Case; China Reports Another Death. Available online: https://www.cidrap.umn. edu/news-perspective/2020/01/japan-has-1st-novel-coronavirus-case-china-reports-another-death (accessed on 28 August 2020).

154. Kornreich, Y.; Jin, Y. The Secret to Taiwan's Successful COVID Response. Available online: https://www.asiapacific.ca/ publication/secret-taiwans-successful-covid-response (accessed on 28 August 2020).

155. Ha, B.T.T.; Quang, L.N.; Mirzoev, T.; Tai, N.T.; Thai, P.Q.; Dinh, P.C. Combating the COVID-19 Epidemic: Experiences from Vietnam. Int. J. Environ. Res. Public Health 2020, 17, 3125. [CrossRef] [PubMed]

156. Nguyen, T.; Malesky, E. Reopening Vietnam: How the Country's Improving Governance Helped It Weather the COVID-19 Pandemic. Available online: https:/ / www.brookings.edu/blog/order-from-chaos/2020/05/20/reopening-vietnam-how-thecountrys-improving-governance-helped-it-weather-the-covid-19-pandemic/ (accessed on 13 June 2020).

157. Hưng, T. IMF đề cao mô hình chống dịch Covid-19 của Việt Nam (The IMF Highly Appreciates the Anti-Epidemic Model Covid-19 of Vietnam). Available online: https://nhandan.com.vn/binh-luan-quoc-te/imf-de-cao-mo-hinh-chong-dich-covid-19 -cua-viet-nam-581579/ (accessed on 9 September 2020).

158. Intelligence.weforum.org Global Issue, COVID-19 Curation: World Economic Forum. Available online: https://intelligence. weforum.org/topics/a1G0X000006O6EHUA0?tab=publications (accessed on 8 August 2020).

159. Walsh, B. Covid-19: The History of Pandemics. Available online: https://www.bbc.com/future/article/20200325-covid-19-thehistory-of-pandemics (accessed on 28 August 2020).

160. Yến, H. WHO: Đại dịch có thể trở nên tồi tệ hơn, nhiều nước đang đi sai hướng (WHO: The Pandemic Could Get Worse, Many Countries Are Going in the Wrong Direction). Available online: https://ncov.moh.gov.vn/web/guest/-/who-ai-dich-co-the-tronen-toi-te-hon-nhieu-nuoc-ang-i-sai-huong (accessed on 8 August 2020).

161. Truong, M. Vietnam's Communist Party Finds a Silver Lining in COVID-19. Available online: https://thediplomat.com/2020/0 3/vietnams-communist-party-finds-a-silver-lining-in-covid-19/ (accessed on 13 October 2020).

162. Vietnamnews.vn Vietnamese Confident in Government's Response to COVID-19: International Survey. Available online: https: / / vietnamnews.vn/ society / 654401/vietnamese-confident-in-governments-response-to-covid-19-international-survey.html (accessed on 8 August 2020).

163. Dölitzsch, C. Global Study About COVID-19: Dalia Assesses How the World Ranks Their Governments' Response to the Pandemic. Available online: https://daliaresearch.com/blog/dalia-assesses-how-the-world-ranks-their-governments-responseto-covid-19/ (accessed on 8 August 2020).

164. Vietnamtimes.org.vn Health Declaration Mobile App Launched to Combat Covid-19 Epidemic. Available online: https:/ vietnamtimes. org.vn/health-declaration-mobile-app-launched-to-combat-covid-19-epidemic-18280.html (accessed on 3 August 2020).

165. Vir.com.vn Vietnam Now in Third Phase of COVID-19 Combat: PM. Available online: https://www.vir.com.vn/vietnam-nowin-third-phase-of-covid-19-combat-pm-75022.html (accessed on 4 August 2020). 
166. Lê, H. Toàn cảnh 3 giai đoạn dịch Covid-19 tại Việt Nam (Overview of the 3 Phases of Covid-19 Pandemic in Vietnam). Available online: https: / thanhnien.vn/thoi-su/toan-canh-3-giai-doan-dich-covid-19-tai-viet-nam-1207707.html (accessed on 1 September 2020).

167. Trần, Q. Mô hình chống dịch "để không ai bị bỏ lại phía sau" của Việt Nam (Vietnam's "Anti-Pandemicc" Model for No One to Be Left Behind). Available online: https:/ / www.baoquangbinh.vn/xa-hoi/202004/mo-hinh-chong-dich-de-khong-ai-bi-bo-laiphia-sau-cua-viet-nam-2176584/ (accessed on 11 September 2020).

168. Mai, N. Không có ai bị bỏ lại phía sau (No One Is Left Behind). Available online: https:/ / baophapluat.vn/dan-sinh/khong-coai-bi-bo-lai-phia-sau-503782.html (accessed on 11 September 2020).

169. Clare, A. COVID-19 in South and Southeast Asia: A Quick Guide. Available online: https://www.aph.gov.au/About_ Parliament/Parliamentary_Departments/Parliamentary_Library/pubs/rp/rp2021/Quick_Guides/COVIDSouthAsia (accessed on 12 October 2020).

170. Vietnam's COVID-19 Success Is A Double-Edged Sword for the Communist Party. Available online: https://thediplomat.com/ 2020/08/vietnams-covid-19-success-is-a-double-edged-sword-for-the-communist-party/ (accessed on 12 October 2020).

171. Dabla-Norris, E.; Gulde-Wolf, A.-M.; Painchaud, F. Vietnam's Success in Containing COVID-19 Offers Roadmap for Other Developing Countries. Available online: https://www.imf.org/en/News/Articles/2020/06/29/na062920-vietnams-success-incontaining-covid19-offers-roadmap-for-other-developing-countries (accessed on 8 August 2020).

172. baochinhphu.vn Kết luận của Bộ Chính trị về chủ trương khắc phục tác động của đại dịch COVID-19 để phục hồi và phát triển nền kinh tế. Available online: http:/ / baochinhphu.vn/Thoi-su/Ket-luan-cua-Bo-Chinh-tri-ve-chu-truong-khac-phuc-tac-dongcua-dai-dich-COVID19-de-phuc-hoi-va-phat-trien-nen-kinh-te/397507.vgp (accessed on 4 September 2020).

173. vtudien.vn Từ điển tiếng Việt,"điện tín" là gì? (Vietnamese Dictionary, What Is “Telegram"?). Available online: https://vtudien.com/viet-viet/dictionary/nghia-cua-tu-điệntín (accessed on 28 July 2020).

174. thuvienphapluat.vn "Công điện" là gì? (What is “Telegram"?). Available online: https://hoidap.thuvienphapluat.vn/hoi-dap/ 1DA37-hd-cong-dien-la-gi.html (accessed on 28 July 2020).

175. vtudien.vn Từ điển tiếng Việt, "Nghị quyết" là gì? (Vietnamese Dictionary, What Is a "Resolution"?). Available online: https://vtudien.com/viet-viet/dictionary/nghia-cua-tu-nghịuyết (accessed on 29 July 2020).

176. luatduonggia.vn Khái niệm, đặc điểm và phân loại quyết định hành chính (Concept, Characteristics and Classification of Administrative Decisions). Available online: https:/ / luatduonggia.vn/phan-loai-quyet-dinh-hanh-chinh/ (accessed on 29 July 2020).

177. vtudien.vn Từ điển tiếng Việt, “Chỉ thị" là gì? (Vietnamese Dictionary, What Is a "Directive"?). Available online: https://vtudien.com/viet-viet/dictionary/nghia-cua-tu-chỉthị (accessed on 30 July 2020).

178. thukyluat.vn "Thông tư" là gì? (What is "Circular"?). Available online: https://nganhangphapluat.thukyluat.vn/tu-van-phapluat/linh-vuc-khac/thong-tu-la-gi-121081 (accessed on 30 July 2020).

179. vtudien.vn Từ điển tiếng Việt, "Thông tư" là gì? (Vietnamese Dictionary, What Is "Circular")? Available online: https://vtudien.com/viet-viet/dictionary/nghia-cua-tu-thôngtư (accessed on 30 July 2020).

180. tailieu.vn Khái niệm thông báo (Annoucement Concept). Available online: https://tailieu.vn/tag/khai-niem-thong-bao.html (accessed on 30 July 2020).

181. vtudien.com Từ điển tiếng Việt, “Kế hoạch" là gì? (Vietnamese Dictionary, What Is "Plan”?). Available online: https://vtudien.com/ viet-viet/dictionary/nghia-cua-tu-kêhoạch (accessed on 9 September 2020).

182. vtudien.com Từ điển tiếng Việt, “Công văn” là gì? (Vietnamese Dictionary, What Is “Dispatch"?). Available online: https:/ /vtudien.com/viet-viet/dictionary/nghia-cua-tu-côngvăn (accessed on 30 July 2020).

183. MOH Công điện của Thủ tướng chính phủ về việc phòng, chống dịch bệnh viêm đường hô hấp cấp do chủng mới của vi rút Corona gây ra (Telegram of the Prime Minister on Prevention and Control of Acute Respiratory Infection Epidemic Caused By New Strain of Corona v. Available online: http:/ /vncdc.gov.vn/vi/phong-chong-dich-benh-viem-phoi-cap-ncov/8573/cong-dien-cua-thutuong-chinh-phu-ve-viec-phong-chong-dich-benh-viem-duong-ho-hap-cap-do-chung-moi-cua-vi-rut-corona-gay-ra (accessed on 23 June 2020).

184. WHO Statement on the Second Meeting of the International Health Regulations (2005) Emergency Committee Regarding the Outbreak of Novel Coronavirus (2019-nCoV). Available online: https:/ /www.who.int/news-room/detail/30-01-2020-statementon-the-second-meeting-of-the-international-health-regulations-(2005)-emergency-committee-regarding-the-outbreak-ofnovel-coronavirus-(2019-ncov) (accessed on 2 September 2020).

185. Vnmission Health Alert-U.S. Embassy Hanoi and Consulate General Ho Chi Minh City. Available online: https://vn.usembassy. gov / health-alert-u-s-embassy-hanoi-and-consulate-general-ho-chi-minh-city/ (accessed on 23 June 2020).

186. Ngà, T.; Linh, N. Chù động phòng chõng dịch bệnh viêm đường hô hấp cấp do chủng mới của virus Corona (nCoV) gây ra (Proactively Prevent and Combat Acute Respiratory Infections Caused by New Strains of Corona Virus (nCoV)). Available online: http: / / vuthuvien.bvhttdl.gov.vn/articledetail.aspx?sitepageid=625\&articleid=10893 (accessed on 23 June 2020).

187. VNA National Steering Committee for Coronavirus Prevention Set Up. Available online: https://en.vietnamplus.vn/nationalsteering-committee-for-coronavirus-prevention-set-up/167936.vnp (accessed on 23 June 2020).

188. Trâm, B. Bệnh nhân thứ 17 dương tính với corona ở Việt Nam từng qua các vùng dịch tại châu Âu (The 17 th Patient Positive for Corona in Vietnam Used to Go Through Epidemic Areas in Europe). Available online: https://forbesvietnam.com.vn/tincap-nhat/benh-nhan-thu-17-duong-tinh-voi-corona-o-viet-nam-tung-qua-cac-vung-dich-tai-chau-au-9580.html (accessed on 5 September 2020). 
189. WHO. WHO Director-General's Opening Remarks at the Media Briefing on COVID-19-11 March 2020. Available online: https://www.who.int/dg/speeches/detail/who-director-general-s-opening-remarks-at-the-media-briefing-on-covid-19---1 1-march-2020 (accessed on 3 August 2020).

190. baochinhphu.vn WHO tuyên bố COVID-19 là đại dịch toàn cầu (The WHO Declared Covid-19 As A Global Pandemic). Available online: http:/ / baochinhphu.vn/Tin-noi-bat/WHO-tuyen-bo-COVID19-la-dai-dich-toan-cau/389702.vgp (accessed on 6 September 2020).

191. forbesvietnam.com.vn WHO công bố Covid-19 là đại dịch toàn cầu (The WHO Declared Covid-19 A Global Epidemic). Available online: https: / forbesvietnam.com.vn/tin-cap-nhat/who-cong-bo-covid19-la-dai-dich-toan-cau-9659.html (accessed on 6 September 2020).

192. tuoitre.vn WHO tuyên bố COVID-19 là đại dịch, bước kế tiếp là gì? (WHO Declares COVID-19 A Pandemic, What's the Next Step?). Available online: https://tuoitre.vn/who-tuyen-bo-covid-19-la-dai-dich-buoc-ke-tiep-la-gi-2020031210361298.htm (accessed on 6 September 2020).

193. tuoitre.vn WHO công bố: COVID-19 là đại dịch, các nước không được khoanh tay (WHO announced: COVID-19 is A Pandemic, Countries Must Not Cross Arms). Available online: https: / / tuoitre.vn/who-cong-bo-covid-19-la-dai-dich-cac-nuoc-khongduoc-khoanh-tay-20200312005910199.htm (accessed on 6 September 2020).

194. baoquocte.vn WHO chính thức tuyên bố Covid-19 là đại dịch toàn cầu (The WHO Officially Declared Covid-19 As A Global Pandemic). Available online: https://baoquocte.vn/who-chinh-thuc-tuyen-bo-covid-19-la-dai-dich-toan-cau-111302.html (accessed on 6 September 2020).

195. PM Chỉ thị số 15/CT-TTg ngày 27 tháng 3 năm 2020 về việc quyết liệt thực hiện đợt cao điểm phòng, chống dịch COVID-19 (Directive No. 15/CT-TTg of 27 March 2020 on Drastically Implementing the Peak Phase of COVID-19 Prevention and Control). Available online: https:/ / thuvienphapluat.vn/van-ban/The-thao-Y-te/Chi-thi-15-CT-TTg-2020-quyet-liet-thuc-hien-dot-caodiem-phong-chong-dich-COVID-19-438342.aspx (accessed on 5 August 2020).

196. chinhphu.vn Hướng dẫn thực hiện Chỉ thị 16/CT-TTg về cách ly xã hội (Guiding the Implementation of Directive 16/CT-TTg on Social Isolation). Available online: https://moh.gov.vn/hoat-dong-cua-lanh-dao-bo/-/asset_publisher/TW6LTp1ZtwaN/ content/huong-dan-thuc-hien-chi-thi-16-ct-ttg-ve-cach-ly-xa-hoi (accessed on 5 September 2020).

197. MOH Chúng ta đã bước sang giai đoạn 3 của "cuộc chiến" chống dịch COVID-19. Available online: https://ncov.moh.gov.vn/ web / guest/- / chung-ta-a-buoc-sang-giai-oan-3-cua-cuoc-chien-chong-dich-covid-19 (accessed on 1 September 2020).

198. kenh14.vn NÓNG: Việt Nam đã có phác đồ điều trị hiệu quả đối với Covid-19 (HOT: Vietnam Already has An Effective Treatment Regimen Against Covid-19). Available online: https:// kenh14.vn/nong-viet-nam-da-co-phac-do-dieu-tri-hieu-qua-doi-voicovid-19-20200219172238233.chn (accessed on 6 September 2020).

199. Hằng, T. Bệnh nhân thứ 16 nhiễm virus corona xuất viện hôm nay (The 16th Patient Infected with Corona Virus Discharged from the Hospital Today). Available online: https:/ / zingnews.vn/benh-nhan-thu-16-nhiem-virus-corona-xuat-vien-hom-nay-post1 051503.html (accessed on 16 July 2020).

200. csis.org Southeast Asia Covid-19 Tracker. Available online: https://www.csis.org/programs/southeast-asia-program/southeastasia-covid-19-tracker-0 (accessed on 12 October 2020).

201. Ngọc, B. 20 nước đặt mua kit xét nghiệm nCoV của Việt Nam (20 Countries Ordered nCoV Test Kits from Vietnam). Available online: https:/ / vnexpress.net/20-nuoc-dat-mua-kit-xet-nghiem-ncov-cua-viet-nam-4070614.html (accessed on 30 May 2020).

202. Hải, V.; Định, T. Hà Nội lập 10 trạm xét nghiệm nhanh Covid-19 (Hanoi Established 10 Rapid Test Stations Covid-19). Available online: https:/ /vnexpress.net/ha-noi-lap-10-tram-xet-nghiem-nhanh-covid-19-4077223.html (accessed on 5 August 2020).

203. Lê, C. Việt Nam phân lập thành công thêm một nhánh nCoV (Vietnam has Successfully Isolated Another nCoV Branch). Available online: https: / /vnexpress.net/viet-nam-phan-lap-thanh-cong-them-mot-nhanh-ncov-4080283.html (accessed on 5 August 2020).

204. Hiếu, C. Việt Nam đã làm chủ 2 phương pháp xét nghiệm Covid-19 (Việt Nam đã làm chủ 2 phương pháp xét nghiệm Covid-19). Available online: https:/ thanhnien.vn/thoi-su/viet-nam-da-lam-chu-2-phuong-phap-xet-nghiem-covid-19-1216627.html (accessed on 6 August 2020).

205. chinhphu.vn Bộ sản phẩm xét nghiệm COVID-19 của Việt Nam được WHO chấp thuận (The Vietnamese COVID-19 Test Kit was Approved by WHO). Available online: https:/ / congannghean.vn/kinh-te-xa-hoi/khoa-hoc-cong-nghe/202004/bo-san-phamxet-nghiem-covid-19-cua-viet-nam-duoc-who-chap-thuan-897953/ (accessed on 4 September 2020).

206. vtv.vn Việt Nam xuất khẩu 20.000 bộ kit xét nghiệm COVID-19 đi 8 nước (Vietnam Exported 20,000 COVID-19 Test Kits to 8 Countries). Available online: https:/ / baothaibinh.com.vn/tin-tuc/13/104218/viet-nam-xuat-khau-20-000-bo-kit-xet-nghiemcovid-19-di-8-nuoc (accessed on 4 September 2020).

207. tuoitre.vn Thêm nhiều tỉnh tiếp tục cho học sinh nghỉ học vì COVID-19 (More Provinces Continue to Drop Pupils and Students out of Schools Because of COVID-19). Available online: https://tuoitre.vn/them-nhieu-tinh-tiep-tuc-cho-hoc-sinh-nghi-hoc-vicovid-19-20200312094950839.htm (accessed on 1 September 2020).

208. Hà, S. Hà Nội họp khẩn khi dịch Covid-19 lan rộng ở Hàn Quốc, Nhật Bản (Hanoi Urgent Meeting When Covid-19 Epidemic Spreading in Korea, Japan). Available online: http:/ / medinet.gov.vn/chuyen-muc/ha-noi-hop-khan-khi-dich-covid-19-lanrong-o-han-quoc-nhat-ban-cmobile1780-24869.aspx (accessed on 3 September 2020). 
209. Thanh, B.H. Phòng ca Covid-19 "siêu lây nhiễm", Hà Nội liên tiếp phát đi 2 công điện khẩn trong đêm (To Prevent the "Super-Contagious" Covid-19 Case, Hanoi Consecutively Sent Out Two Urgent Telegrams at Night). Available online: https:/ /nld.com.vn/thoi-su/phong-ca-covid-19-sieu-lay-nhiem-ha-noi-lien-tiep-phat-di-2-cong-dien-khan-trong-dem-2020 032823583139.htm (accessed on 3 September 2020).

210. V.A Gần 7.000 người Việt về nước từ các "tâm dịch" Covid-19 trong ngày 18/3 (Nearly 7000 Vietnamese Returned Home from "Covid-19" Centers on 18 March). Available online: https:/ / baoquocte.vn/gan-7000-nguoi-viet-ve-nuoc-tu-cac-tam-dich-covid19-trong-ngay-183-111762.html (accessed on 3 August 2020).

211. Bình, T. Người Việt tại Châu Âu ồ ạt về nước, mỗi ngày cả nghìn người (Vietnamese People in Europe Rushed Home, Thousands of People Every Day). Available online: https:/ / www.baogiaothong.vn/nguoi-viet-tai-chau-au-o-at-hoi-huong-moi-ngay-canghin-nguoi-d457097.html (accessed on 6 September 2020).

212. Đỗ, P. Đón chuyến bay thương mại đầu tiên sau thời gian gián đoạn vì dịch Covid-19 (First Commercial Flight After A Covid-19 Interruption). Available online: http:/ / baoquangninh.com.vn/kinh-te/202005/don-chuyen-bay-thuong-mai-dau-tien-sauthoi-gian-gian-doan-vi-dich-covid-19-2481820/ (accessed on 4 September 2020).

213. Thắm, T. Sự hồi phục "ngoạn mục" của hàng không Việt (The "Spectacular" Recovery of Vietnamese Aviation). Available online: https: / / nhipsongdoanhnghiep.cuocsongantoan.vn/thoi-su/su-hoi-phuc-ngoan-muc-cua-hang-khong-viet-3546669. html (accessed on 5 September 2020).

214. Ngọc, D. Vietnam Airlines bay chuyến chở khách đầu tiên đến Trung Quốc sau dịch (Vietnam Airlines Flew Its First Passenger Flight to China After the Outbreak). Available online: https://nld.com.vn/kinh-te/vietnam-airlines-bay-chuyen-cho-khachdau-tien-den-trung-quoc-sau-dich-202007211453237.htm (accessed on 5 September 2020).

215. Thu, H. Từ 0h 23/4, cả nước cơ bản dừng cách ly xã hội (From 23 April the Country Basically Stopped Social Isolation). Available online: https: / / zingnews.vn/tu-0h-234-ca-nuoc-co-ban-dung-cach-ly-xa-hoi-Post1076088.html (accessed on 7 August 2020).

216. Võ, H. Hà Nội ngừng cách ly xã hội từ Oh ngày 23/4 (Hanoi Stopped Social Isolation From 0 h on 23/4). Available online: https: / / thuvienphapluat.vn/tintuc/vn/thoi-su-phap-luat/thoi-su/28522/ha-noi-ngung-cach-ly-xa-hoi-tu-0h-ngay-23-4 (accessed on 7 August 2020).

217. Vũ, A. Nhà nước chỉ nên bao cấp chi phí cơ bản khi cách ly bắt buộc phòng chống Covid-19 (The State should Only Subsidize Basic Costs When Forced Quarantine Against Covid-19). Available online: https:/ thanhnien.vn/thoi-su/nha-nuoc-chi-nenbao-cap-chi-phi-co-ban-khi-cach-ly-bat-buoc-phong-covid-19-1198249.html (accessed on 31 August 2020).

218. Lê, H. Kêu gọi toàn dân ủng hộ phòng, chống dịch Covid-19 (Call on All People to Support the Prevention and Fight Against the Covid-19 Pandemic). Available online: https://thanhnien.vn/thoi-su/keu-goi-toan-dan-ung-ho-phong-chong-dich-covid-19-1 197505.html (accessed on 4 September 2020).

219. vingroup.net Tập đoàn Vingroup-Công ty CP (Vingroup-Joint Stock Company). Available online: https: / / vingroup.net/gioithieu (accessed on 12 September 2020).

220. Hà, T. Vingroup Embarked on Manufacturing Ventilators, Temperature Measuring Machines, Committed to Donating 5000 Breathing Machines to the Ministry of Health (Vingroup Embarked on Manufacturing Ventilators and Thermometers, Committing to Donate 5000 Breathing. Available online: https:/ / tuoitre.vn/vingroup-bat-tay-san-xuat-may-tho-may-do-than-nhiet-cam-kettang-bo-y-te-5-000-may-tho-20200403172417048.htm (accessed on 12 September 2020).

221. Hà, T. Nhắn tin ủng hộ phòng chống COVID-19 được 133 tỉ đồng (Messages to Support COVID-19 Prevention was 133 Billion VNĐ). Available online: https:/ / tuoitre.vn/nhan-tin-ung-ho-phong-chong-covid-19-duoc-133-ti-dong-20200410191725541.htm (accessed on 4 September 2020).

222. GOV Nghị quyết số 42/NQ/CP của Chính phủ ngày 9 tháng 4 năm 2020 về các biện pháp hỗ trợ người dân gặp khó khăn do đại dịch COVID-19 (Resolution No. 42/NQ/CP Issued by the Government Dated on 9 April 2020 on Measures to Support People Facing Difficulties Due). Available online: https://thuvienphapluat.vn/van-ban/lao-dong-tien-luong/nghi-quyet-42-nq-cp-20 20-bien-phap-ho-tro-nguoi-dan-gap-kho-khan-do-covid-19-439526.aspx (accessed on 6 August 2020).

223. Hoàng, T.; Nguyễn, H. Quân đội diễn tập 5 cấp độ chống Covid-19 (The Army Rehearsed 5 Levels Against Covid-19). Available online: https:/ / vnexpress.net/ quan-doi-dien-tap-5-cap-do-chong-covid-19-4063905.html (accessed on 4 August 2020).

224. Đạt, T. "Ghen cô Vy" vào top 10 ca khúc giảm hoang mang mùa dịch Covid-19 ("Jealous Coronavirus" in the Top 10 of the Panic Reduction of Covid-19 Season). Available online: https:/ / thanhnien.vn/gioi-tre/ghen-co-vy-vao-top-10-ca-khuc-giam-hoangmang-mua-dich-covid-19-1194552.html (accessed on 4 September 2020).

225. Kaufman, G. The World is Reacting To the Very Scary COVID-19 with Silliness. Available online: https:/ /www.billboard.com/ articles/news/9330920/coronavirus-parody-songs (accessed on 4 September 2020).

226. Do, L. Musicians Engage Fans Online As Pandemic Takes Center Stage. Available online: https://e.vnexpress.net/news/life/ culture/musicians-engage-fans-online-as-pandemic-takes-center-stage-4085147.html (accessed on 19 August 2020).

227. thethaovanhoa.vn Nhiều người nước ngoài xin chuyển ngữ "Ghen Cô Vy" (Many Foreigners Ask to Translate 'Jealous Coronavirus'). Available online: https://thethaovanhoa.vn/video/giai-tri/nhieu-nguoi-nuoc-ngoai-xin-chuyen-ngu-ghen-co-vyn20200317162312997.htm (accessed on 4 September 2020).

228. Phạm, D. Công an: Bản đồ Covid-19 ở Hà Nội không chính xác (Police: The Map of Covid-19 in Hanoi Is Incorrect). Available online: https:/ / vnexpress.net/ cong-an-ban-do-covid-19-o-ha-noi-khong-chinh-xac-4066909.html (accessed on 4 September 2020). 
229. Lê, A. Thủ tướng Nguyễn Xuân Phúc yêu cầu mọi người dân đeo khẩu trang ở nơi đông người (Prime Minister Nguyen Xuan Phuc Asked All People to Wear Masks in Crowded Places). Available online: https:/ /viettimes.vn/thu-tuong-nguyen-xuanphuc-yeu-cau-moi-nguoi-dan-deo-khau-trang-o-noi-dong-nguoi-383401.html (accessed on 3 August 2020).

230. GOV Thông báo số 98/VPCP ngày 14 tháng 3 năm 2020 về Kết luận của Thủ tướng Chính phủ Nguyễn Xuân Phúc tại cuộc họp thường trực Chính phủ về phòng, chống dịch COVID-19 (Announcement No. 98/VPCP of 14 March 2020 on the Conclusion of the Prime Minister Nguyen). Available online: https:/ / thuvienphapluat.vn/van-ban/The-thao-Y-te/Thong-bao-98-TB-VPCP2020-ket-luan-cua-Thu-tuong-Chinh-phu-phong-chong-dich-COVID-19-437148.aspx (accessed on 3 August 2020).

231. MOH Công văn 1360/BYT-MT ngày 18 tháng 3 năm 2020 về hướng dẫn đeo khẩu trang phòng chống bệnh COVID-19 cho người dân và cộng đồng do Bộ Y tế ban hành (Dispatch No. 1360/BYT-MT Dated 18 March 2020 on Guidelines for Wearing Masks Against COVID-19 Disease for). Available online: https:/ / thuvienphapluat.vn/cong-van/The-thao-Y-te/Cong-van-1360-BYTMT-2020-huong-dan-deo-khau-trang-cho-nguoi-dan-va-cong-dong-437696.aspx (accessed on 3 August 2020).

232. H.A Nhiều bài hát mới ý nghĩa góp phần đẩy lùi dịch Covid-19 (Many Meaningful New Songs Contribute to Repel the Covid-19 Epidemic). Available online: https:/ / baoquocte.vn/nhung-loi-ca-gop-phan-day-lui-dich-covid-19-112101.html (accessed on 3 September 2020).

233. Hy, M. "Ghen cô Vy" ra bản tiếng Anh, fan quốc tế mong ca khúc được vào Billboard ("Jealous Coronavirus" has been Released in English, International Fans Expects the Song to Enter Billboard). Available online: https://thanhnien.vn/van-hoa/ghen-covy-ra-ban-tieng-anh-fan-quoc-te-mong-ca-khuc-duoc-vao-billboard-1208740.html (accessed on 4 September 2020).

234. Hoàng, P. Công bố tuyển tập 60 bài hát chung tay chống dịch Covid-19 (The Collection of 60 Songs Announced to Fight Against the Covid-19 Epidemic). Available online: https:/ /laodongthudo.vn/cong-bo-tuyen-tap-60-bai-hat-chung-tay-chong-dichcovid-19-106512.html (accessed on 4 September 2020).

235. Hoàng, T. Bắt ông Nguyễn Nhật Cảm-giám đốc Trung tâm kiểm soát bệnh tật Hà Nội (Arrest Mr. Nguyen Nhat Cam-Director of Hanoi Center for Disease Control). Available online: https:/ thuvienphapluat.vn/tintuc/vn/thoi-su-phap-luat/thoi-su/28519/ bat-ong-nguyen-nhat-cam-giam-doc-trung-tam-kiem-soat-benh-tat-ha-noi (accessed on 5 September 2020).

236. Hoàng, T. Vụ nâng khống giá máy xét nghiệm COVID-19: Khởi tố thêm 2 trưởng phòng CDC Hà Nội (The Case of Raising the Price of the COVID-19 Laboratory Machine: Prosecuting Two More CDC Hanoi Managers). Available online: https:/ / tuoitre.vn/ vu-nang-khong-gia-may-xet-nghiem-covid-19-khoi-to-them-2-truong-phong-cdc-ha-noi-20200707171843753.htm (accessed on 5 September 2020). 